NBER WORKING PAPER SERIES

\title{
BANKS AS PATIENT FIXED-INCOME INVESTORS
}

\author{
Samuel G. Hanson \\ Andrei Shleifer \\ Jeremy C. Stein \\ Robert W. Vishny \\ Working Paper 20288 \\ http://www.nber.org/papers/w20288
NATIONAL BUREAU OF ECONOMIC RESEARCH
1050 Massachusetts Avenue
Cambridge, MA 02138
July 2014

We are grateful to seminar participants at the 2014 NBER Corporate Finance Meeting and Harvard University for helpful comments, as well as to Malcolm Baker, John Campbell, Eduardo Dávila, Harry DeAngelo, Doug Diamond, Mihir Desai, Gary Gorton, Robin Greenwood, Arvind Krishnamurthy, David Scharfstein, René Stulz, Adi Sunderam, Paul Tucker, Annette Vissing-Jorgensen, and Yao Zeng for valuable suggestions. We also thank Yueran Ma for excellent research assistance. The views expressed herein are those of the authors and do not necessarily reflect the views of the National Bureau of Economic Research.

At least one co-author has disclosed a financial relationship of potential relevance for this research. Further information is available online at http://www.nber.org/papers/w20288.ack

NBER working papers are circulated for discussion and comment purposes. They have not been peerreviewed or been subject to the review by the NBER Board of Directors that accompanies official NBER publications.

(C) 2014 by Samuel G. Hanson, Andrei Shleifer, Jeremy C. Stein, and Robert W. Vishny. All rights reserved. Short sections of text, not to exceed two paragraphs, may be quoted without explicit permission provided that full credit, including $(\subset$ notice, is given to the source. 
Banks as Patient Fixed-Income Investors

Samuel G. Hanson, Andrei Shleifer, Jeremy C. Stein, and Robert W. Vishny

NBER Working Paper No. 20288

July 2014

JEL No. G2,G21,G23

\begin{abstract}
We examine the business model of traditional commercial banks in the context of their co-existence with shadow banks. While both types of intermediaries create safe "money-like" claims, they go about this in different ways. Traditional banks create safe claims by relying on deposit insurance, supported by costly equity capital. This structure allows bank depositors to remain "sleepy": they do not have to pay attention to transient fluctuations in the mark-to-market value of bank assets. In contrast, shadow banks create safe claims by giving their investors an early exit option that allows them to seize collateral and liquidate it at the first sign of trouble. Thus traditional banks have a stable source of funding, while shadow banks are subject to runs and fire-sale losses. These different funding models in turn influence the kinds of assets that traditional banks and shadow banks hold in equilibrium: traditional banks have a comparative advantage at holding fixed-income assets that have only modest fundamental risk, but are relatively illiquid and have substantial transitory price volatility.
\end{abstract}

Samuel G. Hanson

Harvard Business School

Baker Library 361

Soldiers Field

Boston, MA 02163

and NBER

shanson@hbs.edu

Andrei Shleifer

Department of Economics

Harvard University

Littauer Center M-9

Cambridge, MA 02138

and NBER

ashleifer@harvard.edu
Jeremy C. Stein

Department of Economics

Harvard University

Littauer 209

Cambridge, MA 02138

jeremy_stein@harvard.edu

Robert W. Vishny

Booth School of Business

The University of Chicago

5807 South Woodlawn Avenue

Chicago, IL 60637

and NBER

Rvishny@gmail.com 


\section{Introduction}

What is the business of banking? Do banks primarily create value on the liability side of the balance sheet as in theories of banking emphasizing liquidity creation? Does the essence of banking reside on the asset side as in theories emphasizing banks' ability to monitor borrowers? Or does the special nature of banks derive from some synergy between their assets and liabilities? And what defines the role played by traditional banks in a modern financial system where they compete with market-based intermediaries such as "shadow banks”?

To address these questions, we present a model in which traditional and shadow banks coexist in the marketplace. We begin with the premise that a primary function of both types of intermediaries is to create safe, "money-like” claims that are of value to households because they are useful for transactions purposes. However, traditional banks and shadow banks go about this task in different ways. Traditional banks create safe claims by relying on deposit insurance and other aspects of the government safety net, including the lender-of-last resort function. This government insurance comes at a cost, since, e.g., it requires banks to comply with capital requirements and other forms of regulation as well as incur bricks and mortar costs associated with attracting retail depositors. But it also allows their depositors to remain "sleepy": depositors do not have to pay attention to transient fluctuations in the mark-to-market value of bank assets. In contrast, when shadow banks-including broker-dealers and hedge funds-create money-like claims such as repurchase agreements, they rely less on the government safety net, and hence can economize on costly equity capital. However, manufacturing safety instead means that shadow banks have to hold assets that can be easily liquidated at the first sign of trouble by investors who must remain vigilant.

A central feature of our model is that such liquidations by shadow banks create fire-sale effects, in that they temporarily push asset prices below fundamental value. So, on the one hand, traditional banks' more stable deposit funding structure has an advantage, in that it gives them the ability to hold investments to maturity, riding out transitory valuation shocks until prices revert to fundamental values. On the other hand, this stability comes at a cost. Because the endogenous firesale discount is greater when shadow banks hold more of an asset, this tradeoff pins down the equilibrium holdings of any given asset category across intermediary types. In particular, in an interior equilibrium, the relative holdings of banks and shadow banks must be such that the expected loss to a shadow bank from liquidating an asset at a temporary discount to fundamental value is just balanced by the added cost that a traditional bank pays to obtain more stable funding. 
Alternatively, for some types of assets we can have corner solutions, in which case the model speaks to the specialization of traditional and shadow banks in asset holdings.

This logic leads to our main finding: for traditional banks there is a critical synergy between the asset and liability sides of the balance sheet. Issuing stable money-like claims is complementary with investing in fixed-income assets that have only modest fundamental risk, but that are relatively illiquid and may have substantial exposure to interim fire-sale risk and the accompanying transitory price volatility. In our view, this synergy between funding structure and asset choice is at the heart of the business of commercial banking, and is what fundamentally distinguishes traditional banks from shadow banks: traditional banks are patient investors that can invest in illiquid fixed-income assets with little risk of being interrupted before maturity.

While our formal model emphasizes fire sales (Shleifer and Vishny 1992), our message would also emerge in other models in which early liquidation can occur at prices below fundamental value. For example, early liquidation can be costly in models that combine noise trader shocks with limited arbitrageur risk-bearing capacity (DeLong et al 1990, Shleifer and Vishny 1997). ${ }^{1}$ The general point is that we view transitory non-fundamental movements in asset prices as central to understanding financial intermediation, and especially the connection between the asset and liability sides of intermediary balance sheets. A stable funding structure is an important source of comparative advantage for holding assets that are vulnerable to transitory price movements.

After developing the model, we use the Financial Accounts of the United States (formerly the Flow of Funds) to provide some simple aggregate evidence consistent with the model's key predictions. Specifically, looking across fixed income asset classes, traditional banks have a larger market share in more illiquid assets, be they loans or securities. Similarly, looking across financial intermediary types, intermediaries with more stable funding such as traditional banks have asset portfolios that are more illiquid. In this way, our model yields a novel synthesis of several aggregate facts about the structure of financial intermediation.

There is a vast literature on the economic role of banks. Our work connects most closely to two strands of this literature. One strand, formalized first by Gorton and Pennacchi (1990), focuses on the deposit-taking function of banks, and stresses their role in the creation of liabilities which, precisely because of their safety and immunity from adverse-selection problems, are useful as a

\footnotetext{
${ }^{1}$ Alternatively, the mechanism could be liquidation costs that stem from asset specificity or adverse selection.
} 
transactions medium. Banks are special in this view because they are the institutions that create private, or "inside," money. ${ }^{2}$

This liability-centric view of banks surely captures an important element of reality. In particular, it helps make sense of the fact that, in contrast to nonfinancial firms, banks have capital structures that are highly homogenous in both the cross section and the time series-banks are almost always heavily deposit-financed. At the same time, this liability-centric view alone cannot be a complete theory of banking, because it does not speak to the asset side of bank balance sheets. ${ }^{3}$ For example, although it does not necessarily follow as a logical matter, the liability-centric view has led some observers to advocate narrow banking proposals, whereby bank-created money is backed entirely by safe liquid assets, such as Treasury bills. ${ }^{4}$ And yet as a positive description of commercial banking, narrow banking is very far from what we observe in the world. Indeed, we show that money creation through deposit-taking is too expensive for narrow banking to be a viable business strategy for commercial banks.

A second group of theories explicitly addresses the question of what ties together the asset and liability sides of bank balance sheets-i.e., why is it that the same institutions that create private money choose to back their safe claims not by investing in T-bills, but rather by investing in loans and other relatively illiquid assets? What is the nature of the synergy between the two activities? In a classic contribution, Diamond and Dybvig (1983) argue that banks allow households who are unsure of the timing of their consumption needs to more efficiently invest in long-lived projects which are costly to interrupt early. ${ }^{5}$ Diamond and Dybvig emphasize deposit insurance as the source of stability that keeps depositors sleepy and prevents runs. We build on this observation, and use it to address a question that is not taken up by Diamond and Dybvig, namely: what types of assets is it optimal for deposit-insured banks to hold?

\footnotetext{
${ }^{2}$ Recent papers in this vein include Dang, Gorton and Holmstrom (2013), DeAngelo and Stulz (2013), Gennaioli et al (2013), Gorton and Ordonez (2014), Stein (2012), and Krishnamurthy and Vissing-Jorgensen (2013).

${ }^{3}$ A similar observation can be made about asset-centric theories that focus solely on banks' role as delegated monitors (Diamond (1984)). Here banks are seen as a mechanism for dealing with the information and incentive problems that would otherwise make it difficult for credit to be extended to opaque borrowers. Because this work is silent on the structure of bank liabilities, it does not draw a distinction between banks and other non-bank lenders.

${ }^{4}$ See Pennacchi (2012) for a detailed discussion of narrow banking proposals.

${ }^{5}$ Several other studies have focused on potential complementarities between banks' assets and liabilities. Diamond and Rajan (2001) suggest that the fragility of runnable bank deposits disciplines bank management, enhancing the value of illiquid bank loans. Kashyap, Rajan, and Stein (2002) highlight the similarities between demand deposits and loan commitments, and the ability of an institution that offer both products to economize on costly liquidity buffers. Gennaioli, Shleifer, and Vishny (2013) argue that a central function of banks is to provide safe claims, but emphasize asset-side diversification and tranching as technologies for backing such safe liabilities.
} 
To motivate this asset-side question, note that commercial banks hold not only loans, but also marketable securities, often in very substantial amounts. Moreover, these securities holdings have a particular pattern. Banks tend to stay away from the most liquid securities, such as Treasuries, and concentrate their holdings in securities that are less liquid and whose market prices are more volatile. These include mortgage-backed securities, asset-backed securities, and corporate bonds. At the same time, banks do not hold equities, whose cash flows are too risky. These patterns provide an important clue as to the business of traditional banking more generally, and to the complementarity between asset and liability structures, which our model seeks to explain. ${ }^{6}$

Our work is also related to several other familiar themes. First, a number of papers have explored the joint roles of banks and securities markets in allocating credit and satisfying the demand for liquidity (Holmstrom and Tirole 1997, 2011; Diamond 1997). Second, a recent body of work has studied the shadow banking system and its role in the financial crisis (Brunnermeier and Pedersen 2009; Coval, Jurek, and Stafford 2009a and 2009b; Shleifer and Vishny 2010; Gorton and Metrick 2010 and 2011; Shin 2009; Stein 2012; Gennaioli et al 2013; Kacperzcyk and Schnabl 2013; Krishnamurthy, Nagel, and Orlov 2013; Chernenko and Sunderam 2013; Sunderam 2013; Weymuller 2013, Moreira and Savov 2014). Finally, the evidence we develop using the Financial Accounts draws on research which seeks to measure the mismatch between the liquidity of intermediary assets and liabilities (Brunnermeier, Gorton, and Krishnamurthy 2011 and 2013 and Bai, Krishnamurthy, and Weymuller 2013).

The plan for the paper is as follows. In the next section, we present some motivating evidence on the nature of the assets and liabilities of traditional banks, with particular emphasis on banks’ securities holdings. In Section III, we present our model, in which traditional banks and shadow banks compete as potential buyers of assets with varying degrees of fundamental and liquidity risk. The model yields predictions that we then examine empirically in Section IV. Section $\mathrm{V}$ discusses some additional features of modern banking that appear to be consistent with the model. Section VI briefly discusses policy implications of the model and Section VII concludes.

\footnotetext{
6 Taken literally, the Diamond-Dybvig (1983) model does not admit a rationale for banks to hold marketable securities; see Jacklin (1987). And even if taken less literally, it does not make any predictions about the kinds of securities that banks are expected to hold.
} 


\section{Motivating Evidence}

\section{A. Fact 1: Bank liabilities are highly homogeneous}

Banks' liability structures are highly homogeneous: banks are almost always financed largely with deposits. This finding holds both in the cross-section and over time. In the crosssection, Table I shows various balance sheet items as a share of total assets at the end of 2012 for US commercial banks. To assess the cross-sectional heterogeneity in balance sheets, we show the value-weighted average share, the $90^{\text {th }}$ percentile, and the $10^{\text {th }}$ percentile for each item. To avoid the idiosyncrasies associated with the smallest banks, we focus on banks with assets greater than $\$ 1$ billion. Table I reveals a high degree of homogeneity in the amount of deposit funding. The average bank finances $76 \%$ of its assets with deposits. A bank at the $90^{\text {th }}$ percentile in terms of the distribution is $89 \%$ deposit-financed, only a bit more than a bank at the $10^{\text {th }}$ percentile which is $74 \%$ deposit-financed. A similar pattern holds in the time series for the banking industry as a whole. Figure 1 shows the evolution of the aggregate balance sheets of US banks from 1896 to 2012. As shown in Panel A, banks' liability structures have been very stable over the past 115 years. Deposits have financed $80 \%$ of bank assets on average with an annual standard deviation of just $8 \%$.

These patterns are in sharp contrast to those for non-financial firms, where capital structure tends to be far less determinate, both within industries and over time. This suggests that for banksunlike non-financials, and counter to the spirit of Modigliani and Miller (1958)—an important part of their economic value creation takes place on the liability side of the balance sheet, via deposittaking. This is broadly consistent with the literature that has followed Gorton and Pennacchi (1990).

\section{B. Fact 2: Bank assets are more heterogeneous}

There is considerably more heterogeneity on the asset side of bank balance sheets, and in particular in their mix of loans and securities. In the 2012 cross-section, a bank at the $10^{\text {th }}$ percentile of the distribution had a ratio of securities to assets of $6.9 \%$, while for a bank at the $90^{\text {th }}$ percentile the ratio was almost six times higher, at $40.7 \%{ }^{7}$ One interpretation of this heterogeneity is as follows: while lending is obviously very important for a majority of banks, a bank's scale need not be pinned down by the nature of its lending opportunities. Rather, in some cases, it seems that a bank's size is determined by its deposit franchise, and that taking deposits as given, its problem

\footnotetext{
${ }^{7}$ These figures on securities holdings do not include banks' holdings of cash and reverse repo, which averaged 10.2\% and $4.1 \%$ of assets on a value-weighted basis in 2012 .
} 
becomes one of how to best invest them. Again, this liability-centric perspective is very different from how we are used to thinking about non-financial firms, whose scale is almost always presumed to be driven by their opportunities on the asset side of the balance sheet.

\section{Fact 3: Bank securities portfolios do not seem to be precautionary liquidity buffers}

While banks are quite heterogeneous in their loan and securities mix, within the category of securities banks appear to have relatively well-defined preferences. As can be seen in Table I and Panel A of Figure 2, banks hold very little in the way of Treasury and agency securities: these two categories accounted for just $7.7 \%$ and $5.8 \%$ of total securities holdings on a value-weighted basis in 2012. The bulk of their holdings are in agency mortgage-backed securities (MBS) and other types of mortgage-linked securities such as collateralized mortgage obligations (CMOs) and commercial mortgage-backed securities (CMBS): these collectively accounted for $57.7 \%$ of securities holdings in 2012. Also important is the "other" category, which includes corporate and municipal bonds, as well as asset-backed securities, and which accounted for $29.3 \%$ of holdings in 2012.

This composition of banks' securities portfolios is not what one would expect if banks were simply holding securities as a highly liquid buffer stock against unexpected deposit outflows or loan commitment drawdowns. It also appears—superficially, at least—at odds with the narrow-banking premise that one can profitably exploit a deposit franchise simply by taking deposits and parking them in T-bills. Rather, it looks as if banks are purposefully taking on some mix of duration, credit and prepayment exposure in order to earn a spread relative to T-bills. And indeed, over the period 1984 to 2012, the average spread on banks' securities portfolio relative to bills is $1.73 \%$.

In this vein, it is interesting to ask how profitable banks would be in a counterfactual world in which their deposit-taking behavior was exactly the same, but instead of allocating their securities holdings as they actually do, they followed a narrow-banking strategy of investing only in T-bills. The profitability of a narrow bank that takes deposits $D E P$ at a rate $R_{D E P}$ and invests them in T-bills paying $R_{F}$, while incurring deposit-related noninterest expenses of NONINTEXP (e.g., employee salaries, bricks-and-mortar expenses associated with bank branches, and other operating expenses), and earning deposit-related noninterest income of NONINTINC (e.g., services charges on deposit accounts) is given by

$$
\Pi=\left(R_{F}-R_{D E P}\right)+\frac{N O N I N T I N C}{D E P}-\frac{N O N I N T E X P}{D E P} .
$$

We carry out this calculation for the aggregate commercial banking industry from 19842012. To compute the gross deposit spread, $R_{F}-R_{D E P}$, we use the rate on 3-month Treasury bills as 
our proxy for $R_{F}$ and compute $R_{D E P}$ from Call Reports as the interest paid on deposits divided by deposits. Deposit rates appear to embed a significant convenience premium relative to short-term market rates, as the gross deposit spread averages $0.87 \%$ over our 29 year sample. We next add the noninterest income that banks earn from service charges on deposit accounts from Call Reports. This averages $0.49 \%$ of deposits over our sample. Finally, we subtract the non-interest expense associated with deposit-taking. This is not directly available from Call Reports: banks report their total noninterest expense, but we are only interested in that portion attributable to deposit-taking. ${ }^{8}$ As detailed in the Appendix, we use a hedonic-regression approach to infer the expenses associated with deposit-taking. Although these expenses have trended down due to advances in information technology, they remain substantial, averaging $1.30 \%$ of deposits over the past 29 years.

Combining these pieces as in equation (1), we estimate the average profitability of narrow banking between 1984 and 2012 to be $0.06 \%$ of deposits $(0.06 \%=0.87 \%+0.49 \%-1.30 \%)$. ${ }^{9}$ In other words, the interest rate differential between deposits and short-term marketable rates and the associated fee income is largely offset by the direct costs of operating a deposit-taking franchise. Given these numbers, it is perhaps not surprising that banks choose to invest in riskier securities that earn a spread relative to T-bills. Of course, the large costs of deposit-taking that we document ultimately represent an endogenous choice for traditional banks, and so must be explained as an equilibrium outcome in any fully satisfactory model. For example, banks could always choose to hold down costs by offering fewer physical branch services to their customers, similarly to moneymarket mutual funds. We return to the endogeneity of deposit-taking expenses below.

\section{Discussion}

Our synthesis of these stylized facts is that traditional banks are in the business of taking deposits and investing these deposits in fixed-income assets that have certain well-defined risk and liquidity attributes, but which can be either loans or securities. The information-intensive nature of traditional lending — in the Diamond (1984) delegated monitoring sense-while clearly important in many cases, may not be the defining feature of banking. Rather, the defining feature may be that, whether they are information-intensive loans, or relatively transparent securities, banks seek to

\footnotetext{
${ }^{8}$ In 2012, banks had non-interest operating expenses equal to $2.96 \%$ of total assets. These can be decomposed into wage and salary expenses of $1.32 \%$, building occupancy expenses of $0.32 \%$, and other expenses of $1.32 \%$.

${ }^{9}$ This $0.06 \%$ figure is probably an upper bound on the profitability of narrow banking. As explained in the Appendix, our methodology for attributing bank expenses to different activities leaves an unallocated cost, which can be thought of as fixed overhead. This overhead cost averages $0.63 \%$ of deposits from 1984-2012. If $50 \%$ of this amount is allocated back to deposit-taking, the estimated profitability of narrow banking drops to $-0.25 \%$.
} 
invest in fixed-income assets that have some degree of price volatility and illiquidity, and so offer a higher return than very liquid and safe Treasury securities. In this sense, small business loans, assetbacked securities, and CMOs are on one side of the fence, and Treasuries on the other.

Before proceeding, we should address a natural first reaction to this interpretation. Perhaps banks’ propensity to invest in risky securities merely reflects the fact that they are taking advantage of the put option created by deposit insurance. The evidence we have assembled on the patterns of banks’ securities holdings may just reflect a moral hazard problem, and nothing more.

One way to address this hypothesis is to redo the analysis in Panel A of Figure 2, restricting the sample to those banks with the highest levels of capital at any point in time- those above the median of the distribution by the ratio of equity to assets. This is done in Panel B of Figure 2. The basic patterns for highly capitalized banks in Panel B are very similar to those in Panel A for all banks. Given that these highly capitalized banks are less likely to impose losses on the depositinsurance fund, we suspect that there is something deeper here than can be explained by a simple appeal to deposit-insurance-induced moral hazard.

\section{Model}

We develop a simple model in which banks and shadow banks compete as buyers of a collection of assets with different degrees of fundamental and liquidity risk. The essence of the tradeoff is that banks pay more-by raising more equity capital—to gain access to governmentprovided deposit insurance and hence to create money-like claims that are not only safe for investors in the short run, but also stable, and unlikely to run when there is bad news. This stability allows banks to avoid inefficient fire sales of their assets.

\section{A. Setting}

The basic structure of the model is similar to Stein (2012). The model has three dates, $t=0$, 1 and 2 . There are $N$ long-lived risky assets indexed by $i=1,2, \ldots, N$. Asset $i$ is available in a fixed supply of $Q_{i}$. For simplicity, we assume that the payoffs on these assets are perfectly correlated, and assets only differ in the magnitudes of these payoffs in the bad state of the world. The individual assets in our model might correspond to corporate loans, mortgages, mortgage-backed securities (MBS), US Treasuries, or even equities.

The model features three types of actors: households, traditional banks, and shadow banks. Households do not directly own any of the risky assets. Instead, households invest in safe and risky 
claims issued by traditional and shadow banks, which in turn back these claims by holding the underlying risky assets. Intermediation is efficient here because households are willing to pay a premium for completely safe claims, and some form of intermediation is required to create safetynone of the primitive assets are themselves safe.

Outside of this demand for safe money-like claims, households are assumed to be risk neutral. In other words, once a claim has any risk at all, the discount rate applied by households is fixed at a discretely higher level. This corresponds to the following household utility function, taken from Stein (2012)

$$
U=C_{0}+\beta E\left[C_{2}\right]+\gamma M,
$$

where the notational convention is that a household has $M$ dollars of money-like claims if it has claims that are guaranteed to pay off an amount $M$ at $t=2$. The discount factor applied to all risky claims is thus $\beta \leq 1$ while the discount factor applied to safe, money-like claims is $\beta+\gamma$ where $\gamma \geq$ 0 . The former follows from the observation that a household is indifferent between having $\beta$ units of time- 0 consumption and a risky claim that delivers one unit of time- 2 consumption in expectation. The latter follows from the fact that a household is indifferent between having $\beta+\gamma$ units of time-0 consumption and a riskless claim that always delivers one unit of time- 2 consumption. Such a claim delivers $\beta$ units of utility from expected future consumption, along with additional $\gamma$ units of utility in current monetary services.

When $\gamma>0$, the discount rate applied to safe, money-like claims, $1 /(\beta+\gamma)$, is less than the discount rate applied to risky claims, $1 / \beta$. As in Stein (2012), Gennaioli et al. (2013), and DeAngelo and Stulz (2013), the assumptions of the Modigliani-Miller (1958) theorem no longer hold and the value of a risky asset may depend on the way it is financed using safe and risky claims.

The timing of the model is as follows. Each asset $i$ pays $R$ at $t=2$ if the aggregate economic state of the world is good, but a lower amount $z_{i}<R$ if the aggregate economic state at $t=2$ is bad. At time 1 , there is an interim news event about the future economic state. With probability $p$, the interim news is good, which means that the aggregate state will be good at time 2 and all assets will definitely pay $R$. With probability $(1-p)$, the news is bad, which means that there is a subsequent probability of $(1-q)$ of the bad state and low payoff on all assets at time 2. Thus, in the bad-news state at time 1 , the fundamental value of asset $i$ is $F_{i}=q R+(1-q) z_{i}$. 
Time $t=0$

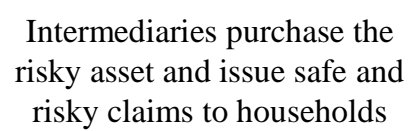

Time $t=1$

Bad state news arrives with probability 1-p. Shadow banks must sell at a discount, $k_{i}$. Traditional banks are able to hold to maturity.

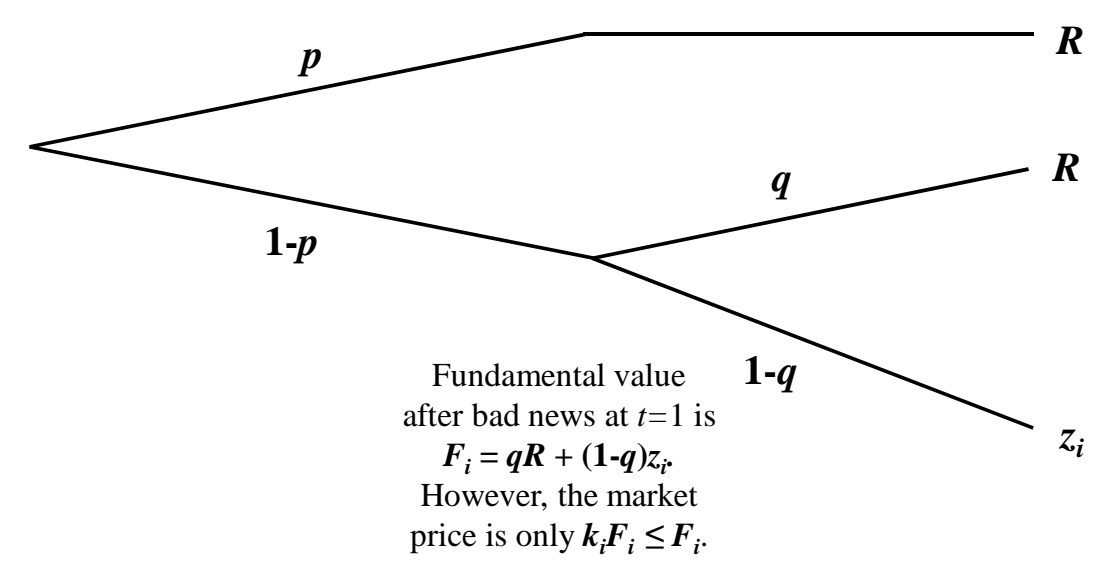

Our central assumption deals with the difference between the fundamental value of asset $i$ at time 1 , and its market value. We assume that, if there is bad news at time 1 , the market value of asset $i$ is $k_{i} F_{i} \leq F_{i}$. When $k_{i}<1$, this market price reflects a fire-sale discount to fundamental value. The value of $k_{i}$ is endogenous and asset-specific and depends on the equilibrium quantity of asset $i$ that is liquidated at time 1 . We return to this feature momentarily.

\section{B. Intermediation structures}

To examine the different ways the risky assets can be held and used as backing to create safe claims, we consider two intermediation structures: traditional banking and shadow banking. At $t=$ 0 , households can invest in either traditional bank deposits or shadow bank deposits, both of which are completely safe and are valued at $\beta+\gamma$ per dollar paid at $t=2$. Alternatively, households can buy bank equity or shadow bank equity, both of which are risky and are valued at $\beta$ per dollar paid in expectation at $t=2$. In equilibrium, fraction $\mu_{i}$ of risky asset $i$ is purchased by shadow banks at $t=0$ and fraction $1-\mu_{i}$ is purchased by traditional banks. We examine how the equilibrium market shares of traditional and shadow banks vary as we change the properties of the asset in question. 


\section{B.1. Traditional banks}

A traditional bank uses deposit insurance and a stable, hold-to-maturity strategy to create safe short-term claims. We assume that, in order to protect taxpayers, the government imposes a particular form of actuarially fair risk-based capital regulation: the bank is required to hold enough capital against any asset $i$ such that the deposit insurer never suffers losses in equilibrium. Since the bank plans to always hold the risky asset to maturity, the maximum amount of safe money-like claims that can be created against asset $i$ in this regulatory regime is $z_{i}$, which is the worst-case payoff at time 2. To satisfy the risk-based capital rule, the remainder of the asset purchase must be financed by raising risky equity capital which is more expensive.

In the literal context of the model, this capital regulation is the only cost to being a depositinsured bank with stable funding, as opposed to a shadow bank with unstable funding. More broadly, however, one might interpret what we are calling the cost of equity capital as encompassing a variety of other costs that go along with being a traditional bank. These include the costs of other types of regulation, as well as the bricks-and-mortar costs of setting up the sort of branch network that attracts retail depositors.

The total value of claims the bank can issue at time 0 using the risky asset $i$ as backing is

$$
\begin{aligned}
& V_{i}^{B}= \overbrace{(\beta+\gamma) z_{i}}^{\text {Value of bank deposits }}+\overbrace{\beta(p+(1-p) q)\left(R-z_{i}\right)}^{\text {Value of bank equity }} \\
&=\overbrace{\gamma z_{i}}^{\text {Money premium }}+\beta \overbrace{\left[p R+(1-p) F_{i}\right]}^{\text {Expected cash flows }},
\end{aligned}
$$

where, again, $F_{i}=q R+(1-q) z_{i}$ is the fundamental value of asset $i$ in the bad state at $t=1$. In any equilibrium where banks hold security $i$, banks’ zero profit condition ensures that the market value of security $i$ equals $V_{i}^{B}$. Because households are willing to pay a premium for absolutely safe claims, equation (3) shows that the total value of claims issued by banks exceeds the expected cash flows on the risky asset discounted at the risky rate: banks capture a money premium of $z_{i}$ because they can use the risky asset to back $z_{i}$ units of safe money-like claims.

\section{B.2. Shadow banks}

An alternative intermediation structure is a shadow bank, which is a composite structure consisting of a highly-leveraged intermediary (HL) such as a broker-dealer or a hedge fund, along 
with a money market fund (MMF). The HL buys the risky asset, and issues short-term repo against it, which is then held by the MMF. MMF deposits and HL equity are owned by households.

The MMF has no capital, so for its deposits to be riskless investments for households the repo that the MMF holds must also be made riskless. The way these repo claims are kept safe is that if there is bad news at time 1 , the MMF seizes the collateral and sells it at the fire-sale price of $k_{i} F_{i}$. The maximum amount of safe money that can be created by a shadow bank is therefore $k_{i} F_{i}$. Unlike traditional bank depositors protected by deposit insurance and bank equity capital, an MMF that invests in repo cannot afford to sleep through time 1; the MMF's ability to pull the plug at this interim date is essential to keeping its claim safe. Shadow banking deposits are thus an endogenous form of "hot" money: they are unstable rather than stable short-term funding.

The total value of claims the shadow banking system can create using the risky asset $i$ as a backing is then given by

$$
\begin{aligned}
V_{i}^{S}\left(k_{i}\right)= & \overbrace{(\gamma+\beta) k_{i} F_{i}}^{\text {Value of MMF deposits }}+\overbrace{\beta p\left(R-k_{i} F_{i}\right)}^{\text {Value of HL equity }} \\
& =\overbrace{\gamma k_{i} F_{i}}^{\text {Money premium }}+\beta \overbrace{\left[p R+(1-p) k_{i} F_{i}\right]}^{\text {Expected cash flows }} .
\end{aligned}
$$

In any equilibrium where shadow banks hold security $i$, their zero profit condition ensures that the market value of security $i$ must equal $V_{i}^{S}\left(k_{i}\right)$.

\section{Equilibrium}

We assume that shadow banks face a downward-sloping demand curve at time 1 , so the firesale price is a decreasing function of the amount of the asset that is liquidated. Formally, let $0 \leq \varphi_{i}$ be an exogenous parameter that indexes the illiquidity in the secondary market. We assume that $\partial k\left(\mu_{i}, \varphi_{i}\right) / \partial \mu_{i} \leq 0$, so demand is downward sloping, and $\partial^{2} k\left(\mu_{i}, \varphi_{i}\right) / \partial \mu_{i} \partial \varphi_{i} \leq 0$, so more illiquid assets have steeper demand curves. Finally, as a normalization, we assume that $k\left(\mu_{i}, 0\right)=1$ for all $\mu_{i}$ : when $\varphi_{i}=0$, the asset is perfectly liquid and there is never any fire-sale discount. As shown in the Appendix, a fire-sale discount of this form can be micro-founded as in Stein (2012). ${ }^{10}$

\footnotetext{
${ }^{10}$ Specifically, we assume that the risky asset is sold to a third type of intermediary (also owned by households) who has fixed resources and access to outside investment opportunities at $t=1$. Since these opportunities are characterized by diminishing returns to scale, shadow banks must offer larger discounts relative to fundamental value to induce these intermediaries to purchase more assets, thereby foregoing increasingly productive outside opportunities. In this context,
} 
Since intermediaries are risk-neutral and there are no benefits of diversification built into our model, intermediaries' willingness to hold asset $i$ is not impacted by their holdings of asset $j \neq i$. As a consequence, market equilibrium in any asset $i$ naturally decouples from that in asset $j \neq i$. An equilibrium for asset $i$ is a $\mu_{i}^{*}$ such that

$$
\begin{array}{ll}
V_{i}^{B}=V_{i}^{S}\left(k\left(\mu_{i}^{*}, \varphi_{i}\right)\right) & \text { for } \mu_{i}^{*} \in(0,1) \\
V_{i}^{B}>V_{i}^{S}\left(k\left(0, \varphi_{i}\right)\right) & \Rightarrow \mu_{i}^{*}=0 \\
V_{i}^{B}<V_{i}^{S}\left(k\left(1, \varphi_{i}\right)\right) & \Rightarrow \mu_{i}^{*}=1 .
\end{array}
$$

The model admits either interior outcomes or corner solutions, depending on the asset-specific values of $z_{i}$ and $\varphi_{i}$. It is consistent with the possibility that some assets (e.g., highly illiquid loans) are held only by banks, some (e.g., Treasuries) are held predominantly by shadow banks, and some (e.g.,MBS) are held in significant amounts by both intermediary types.

Formally, since $\partial V_{i}^{S}\left(k\left(\mu_{i}, \varphi_{i}\right)\right) / \partial \mu_{i}=\left(\partial V_{i}^{S} / \partial k\right) \times\left(\partial k / \partial \mu_{i}\right) \leq 0$, security $i$ is held entirely by traditional banks when $V_{i}^{B}>V_{i}^{S}\left(k\left(0, \varphi_{i}\right)\right)$ and entirely by shadow banks when $V_{i}^{B}<V_{i}^{S}\left(k\left(1, \varphi_{i}\right)\right)$. Since shadow banks dominate traditional banks when there is no fire-sale discount (i.e., we always have $\left.V_{i}^{B}<V_{i}^{S}(1)\right)$, we only have a corner equilibrium where the assets is held entirely by traditional banks when $k\left(0, \varphi_{i}\right)<1$. By contrast, if $k\left(0, \varphi_{i}\right)=1$, then shadow banks must always hold some of the asset in equilibrium.

At an interior equilibrium where both traditional and shadow banks hold the security, the fire-sale discount $k_{i}$ is such that both traditional and shadow banks earn zero profits by buying the asset and issuing claims backed by it. Thus, at an interior equilibrium, we have

$$
\overbrace{(1-p) \beta \times\left[1-k\left(\mu_{i}^{*}, \varphi_{i}\right)\right] \times F_{i}}^{\begin{array}{c}
\text { Marginal benefit of stable funding: } \\
\text { avoiding fire-sale liquidations }
\end{array}}=\overbrace{\gamma \times\left[k\left(\mu_{i}^{*}, \varphi_{i}\right) \times F_{i}-z_{i}\right]}^{\begin{array}{c}
\text { Marginal cost of stable funding: } \\
\text { reduced money creation }
\end{array}} .
$$

Equation (6) is the central equation of the model. It says that the mix between shadow banks and traditional banks must be such that marginal benefit of stable bank funding equals the marginal cost

differences across assets in $\varphi_{i}$ reflect differences in the number of potential second-best holders of each asset-i.e., differences in asset specificity.

${ }^{11}$ Implicitly, by requiring $\mu \in[0,1]$, we are imposing a short-sale constraint for both traditional and shadow banks. 
of stable funding. ${ }^{12}$ Stable funding allows traditional banks to avoid the fire-sale liquidation discount if the bad state occurs at time 1. This benefit of traditional banks relative to shadow banks is captured by the left-hand-side of (6). However, precisely because investors can get out early, the market can generate a larger amount of unstable short-term funding than of stable funding using a given asset as backing. This cost of traditional banking relative to shadow banks is captured by the right-hand-side of (6). In summary, although traditional banks have more stable funding than shadow banks, this stability comes at a price: traditional banks create fewer money-like claims than shadow banks.

Solving equation (6), the equilibrium fire-sale discount is

$$
k_{i}^{*}=k\left(\mu_{i}^{*}, \varphi_{i}\right)=\frac{\gamma z_{i}+\beta(1-p) F_{i}}{\gamma F_{i}+\beta(1-p) F_{i}} .
$$

Finally, inverting the $k\left(\mu_{i}, \varphi_{i}\right)$ function, the equilibrium fraction of asset $i$ held by shadow banks is ${ }^{13}$

$$
\mu_{i}^{*}=k_{i}^{-1}\left(\frac{\gamma z_{i}+\beta(1-p) F_{i}}{\gamma F_{i}+\beta(1-p) F_{i}}\right) .
$$

To take a simple parametric example, assume $k\left(\mu_{i}, \varphi_{i}\right)=1-\varphi_{i} \times \mu_{i}$. In this case, we have $\mu_{i}^{*}=1$ if $\varphi_{i}=0$-i.e., the asset is held exclusively by shadow banks if there is no fire-sale discount—and

$$
\mu_{i}^{*}=\min \left\{\frac{1-k_{i}^{*}}{\varphi_{i}}, 1\right\}=\min \left\{\frac{1}{\varphi_{i}} \frac{\gamma\left(F_{i}-z_{i}\right)}{\gamma F_{i}+\beta(1-p) F_{i}}, 1\right\},
$$

if $\varphi_{i}>0$, so that $\mu_{i}^{*} \rightarrow 0$ as $\varphi_{i} \rightarrow \infty$.

The equilibrium in our model is in the spirit of Miller (1977). While the aggregate mix of unstable $\left(\mu_{i}\right)$ versus stable funding $\left(1-\mu_{i}\right)$ for each asset $i$ is pinned down, so long as we are in an interior equilibrium, any small intermediary is indifferent between setting up shop as a bank or as a shadow bank. Relatedly, the model is silent about the boundaries of financial firms-e.g., whether a holding company winds up housing both traditional and shadow banking operations.

\footnotetext{
12 The left-hand side of equation (6) is the private benefit of avoiding fire-sales that is internalized by an individual intermediary choosing between the traditional and shadow banking forms. As Stein (2012) shows, this differs from the total social benefits of avoiding fire-sales because binding, price-dependent collateral constraints open the door to pecuniary externalities. We return to this point in Section VI where we explore the policy implications of the model.

${ }^{13}$ Formally, the function $k_{i}^{-1}(x)$ is implicitly defined by $x=k\left(k_{i}^{-1}(x), \varphi_{i}\right)$.
} 
Equation (6) says that the equilibrium fire-sale discount is locally independent of asset illiquidity $\varphi_{i}$ at an interior equilibrium where both traditional and shadow banks hold the asset. In this region, a change in asset illiquidity impacts the mix of asset holders - an increase in illiquidity raises the market share of banks_-but leaves the fire-sale discount unchanged. However, if the assets are sufficiently liquid ( $\varphi_{i}$ is very low), the market share of traditional banks is eventually driven to zero, so the fire-sale discount is increasing in asset illiquidity for very low levels of $\varphi_{i}$.

\section{Comparative statics}

The model can be used to characterize the kinds of assets for which the traditional banking model dominates. To do so, we must examine the roles of the two factors that drive the tradeoff between traditional banks and shadow banks: the money premium for safe claims which is controlled by $\gamma$ and the strength of the fire-sale effect which is controlled by $\varphi_{i}$.

First, if $\gamma=0$ and $\partial k\left(\mu_{i}, \varphi_{i}\right) / \partial \mu_{i}<0$, we have $\mu_{i}^{*}=0$-the risky asset is held entirely by traditional banks. If there is no premium for safe claims, shadow banking is dominated by traditional banking: unstable short-term debt forces inefficient liquidations and has no offsetting monetary benefits relative to stable deposit funding.

Conversely, if $\gamma>0$ and $\varphi_{i}=0$ so that $k\left(\mu_{i}, 0\right)=1$ for all $\mu_{i}$, then $\mu_{i}^{*}=1$ - the asset is held entirely by shadow banks. The entire advantage of traditional banks' stable funding is that it enables them to ride out temporary departures of price from fundamental value without liquidating assets. If there is no fire-sale risk and the price at time 1 always equals fundamental value, then stable funding has no value; however, when $\gamma>0$, raising stable funding is always more costly than raising unstable funding.

The ideal asset for a traditional bank is one that has very little fundamental cash-flow risk (i.e., $z_{i}$ is high so risk-based capital rules allow a bank to use it to back a lot of money-like deposits), but that is exposed to meaningful interim price re-pricing risk (i.e., $\varphi_{i}$ is high so fire-sale risk looms large for its shadow-bank counterparts). In general, when both $\gamma>0$ and $\varphi_{i}>0$, there is a meaningful trade-off between the two intermediation structures and we will have an interior equilibrium.

In the case of an interior equilibrium, we can ask how the equilibrium market shares of shadow banks $\left(\mu_{i}^{*}\right)$ and traditional banks $\left(1-\mu_{i}^{*}\right)$ vary with the exogenous model parameters. 
Specifically, differentiating equation (8), we immediately obtain the following comparative statics for the fraction of an asset held by traditional banks:

1. $\partial\left(1-\mu_{i}^{*}\right) / \partial \varphi_{i}>0$ : An increase in asset illiquidity increases the equilibrium share held by traditional banks. By assumption, an increase in asset illiquidity makes the demand curve for fire-sale liquidations at time 1 steeper. Although a change in asset illiquidity $\varphi_{i}$ has no effect on the equilibrium level of the fire-sale discount in (7), this change alters the mapping between the ownership mix and the fire-sale discount in (8). When $\varphi_{i}$ is high, the fire-sale discount is highly sensitive to the volume of forced sales by shadow banks, so traditional banks end up holding more of the asset in equilibrium.

2. $\partial\left(1-\mu_{i}^{*}\right) / \partial z_{i}>0$ : An increase in the worst-case cash flow $z_{i}$ increases the share of the risky asset $\boldsymbol{i}$ held by traditional banks in equilibrium. An increase in $z_{i}$ reduces the moneycreation advantage of shadow banks relative to traditional banks, and therefore needs to be compensated by a rise in $k_{i}^{*}$ which implies a rise in $1-\mu_{i}^{*}$ to restore equilibrium indifference between traditional and shadow banks. We think of a higher $z_{i}$ as being associated with less fundamental cash-flow risk. Thus, all else equal, traditional banks have a comparative advantage at holding assets with little fundamental cash-flow risk.

Taken together, these two results suggest that traditional banks have a comparative advantage at holding illiquid fixed income assets-i.e., assets that can experience significant temporary price dislocations, but at the same time, have only modest fundamental risk. Agency MBS might be a leading example of such an asset, since they are insured against default risk, but are considerably less liquid than Treasury securities, and for a given duration, have more price volatility, since there is significant variability in the MBS-Treasury spread.

The model also explains why banks are not well-suited to investing in equities-equities simply have too much fundamental downside risk. Because their value can fall very far over an extended period of time-i.e., because their $z_{i}$ is close to zero-equities cannot be efficiently used as backing to create safe two-period claims. As such, they are not good collateral for bank money. By contrast, to the extent that they are highly liquid, they do make suitable collateral for very shortterm repo financing. In other words, equities can be used to back some amount of shadow-bank money. 
In addition, we have the following comparative statics which impact all assets:

3. $\partial\left(1-\mu_{i}^{*}\right) / \partial \gamma<0$ : An increase in the money premium on safe claims lowers traditional banks' equilibrium market share of all risky assets. When the premium associated with safe money-like claims is higher, the fire-sale discount must rise to maintain equilibrium (i.e., $k_{i}^{*}$ must fall), so the fraction of risky assets held by shadow banks, $\mu_{i}^{*}$, must rise.

4. $\partial\left(1-\mu_{i}^{*}\right) / \partial p<0$ : An increase in the probability of good news at time 1 lowers the share of all risky assets held by traditional banks. When the interim good state is more likely, a larger fire-sale discount (lower $k_{i}^{*}$ ) is needed to restore indifference and the market share of shadow banks, $\mu_{i}^{*}$, must rise in equilibrium. Intuitively, bank’s stable funding structure functions as a costly form of insurance against fire-sale risk; this insurance naturally becomes less valuable when a fire sale is less likely (i.e., when $p$ rises).

Comparative static \#3 suggests that an increase in the demand for safe, money-like assets should trigger a migration of intermediation from traditional to shadow banking. Indeed, some observers have argued that such an increase in money demand played a role in fueling the rapid growth of shadow banking prior to the recent financial crisis. ${ }^{14}$ Comparative static \#4 suggests that intermediation activity tends to migrate away from traditional banks and towards shadow banks during economic expansions when $p$ is high. In summary, our model provides a way of understanding why traditional banks lost significant market share to shadow banks during the runup to the recent financial crisis.

\section{Further Evidence}

In this section, we provide some simple aggregate evidence bearing on the model's predictions. We think of this analysis more as a synthesis of known high-level facts about the structure of financial intermediation than as a true test of the model. We first describe how we take the model to the data, then our measurement approach, and finally the results of some simple crosssectional regressions suggested by the model.

\footnotetext{
${ }^{14}$ See for instance Bernanke (2005), Gennaioli et al (2013), Gourinchas and Jeanne (2012), Krishnamurthy and VissingJorgensen (2013), and Caballero and Farhi (2013).
} 
A. Taking the model to the data

A.1. The cross-section of asset classes

A key testable implication of our model is that, all else equal, traditional banks should hold a higher market share in more illiquid assets: $\partial\left(1-\mu_{i}^{*}\right) / \partial \varphi_{i}>0$.

Prediction 1: Looking across assets and holding constant fundamental asset risk, banks should have a larger market share in asset classes that are more illiquid.

Our model features just two intermediary types: traditional banks with stable funding and shadow banks with unstable funding. In reality, there are many intermediary types with a range of funding stability. Generalizing our theory, we would expect intermediaries with more stable funding to hold more illiquid assets with high fire-sale risk.

Prediction 2: Looking across assets and holding constant fundamental asset risk, more illiquid asset classes should be held by intermediary types with greater funding stability.

\section{A.2. The cross-section of intermediary types}

Since our theory has predictions for the cross-section of asset types, it naturally generates related predictions for the cross-section of intermediary types. Specifically, the portfolio share of shadow banks in asset $i$ is

$$
w_{i}^{S^{*}}=\frac{\mu_{i}^{*} Q_{i}}{\sum_{k=1}^{N} \mu_{k}^{*} Q_{k}},
$$

and the portfolio share of traditional banks in asset $i$ is

$$
w_{i}^{B^{*}}=\frac{\left(1-\mu_{i}^{*}\right) Q_{i}}{\sum_{k=1}^{N}\left(1-\mu_{k}^{*}\right) Q_{k}} .
$$

It follows trivially from the comparative statics derived above that $\partial w_{i}^{S^{*}} / \partial \varphi_{i}<0, \partial w_{i}^{S^{*}} / \partial z_{i}<0$, $\partial w_{i}^{B^{*}} / \partial \varphi_{i}>0$, and $\partial w_{i}^{B^{*}} / \partial z_{i}>0$. In other words, shadow bank portfolios are tilted towards assets that are more liquid or have more fundamental downside-risk, whereas traditional bank portfolios are tilted towards assets that are more illiquid and have less fundamental downside-risk.

The average illiquidity of assets held by shadow banks is

$$
\Phi^{S^{*}}=\sum_{i=1}^{N} w_{i}^{S^{*}} \varphi_{i}
$$

and the average illiquidity of asset held by commercial banks is

$$
\Phi^{B^{*}}=\sum_{i=1}^{N} w_{i}^{B^{*}} \varphi_{i}
$$


If all assets have the same $z_{i}$, in equilibrium we have

$$
\Phi^{B^{*}}>\Phi^{S^{*}}
$$

—i.e., the asset portfolios of traditional banks would be more illiquid than those of shadow banks.

Prediction 3: The asset portfolios of commercial banks are more illiquid than the asset portfolios of shadow banks, controlling for fundamental risk.

As above, we can generalize this to obtain a prediction that we can apply to the broader cross-section of intermediary types, including insurers and finance companies.

Prediction 4: Comparing across intermediaries, those with more stable funding should have asset portfolios that are more illiquid, controlling for fundamental risk.

\section{B. Measurement}

Let $j$ index intermediary types and let $i$ index instrument types-i.e., different types of assets or liabilities. Let $I L L I Q U I D_{i} \in[0,1]$ measure the illiquidity of asset type $i$. For instance, US Treasuries should have ILLIQUID ${ }_{i}=0$ and small business loans might have ILLIQUID $=1$. $^{2}$ Similarly, let $\operatorname{MATURITY}_{i} \in[0,1]$ measure the contractual maturity length of liability type $i$ and STICKY $Y_{i} \in[0,1]$ measure the stickiness of liability type $i$. Stickiness is opposite of runniness, which is the tendency for liability holders to withdraw funds following an adverse shock. For instance, short-term commercial paper might have $S T I C K Y_{i}=0$, while long-term (non-redeemable) equity would have $S T I C K Y_{i}=1$.

Let $A_{j i}$ and $L_{j i}$ denote intermediary $j$ 's assets and liabilities of instrument type $i$ and let

$A_{j}=\sum_{i} A_{j i}=\sum_{i} L_{j i}$. denote the total assets of intermediary type $j$. Then the Asset Illiquidity Index for intermediary type $j$ is defined as the weighted average illiquidity of its asset holdings

$$
A_{-} \text {ILLIQUID }_{j}=\frac{\sum_{i} A_{j i} \times I L L I Q U I D}{i} .
$$

The Liability Maturity Index for intermediary type $j$ is the weighted average contractual maturity of its liabilities

$$
L_{-} \operatorname{MATURITY}_{j}=\frac{\sum_{i} L_{i j} \times M A T U R I T Y}{i} .
$$

Finally, the Liability Stickiness Index for intermediary type $j$ is the weighted average stickiness of its liabilities 


$$
L_{-} S T I C K Y_{j}=\frac{\sum_{i} L_{j i} \times S T I C K Y_{i}}{A_{j}} .
$$

Our measurement approach is in the spirit of Brunnermeier, Gorton, and Krishnamurthy (2011, 2013), who suggest constructing a liquidity mismatch index — the difference between asset illiquidity and funding liquidity-for different financial intermediaries. This approach is implemented in Bai, Krishnamurthy, and Weymuller (2013) for bank holding companies.

We assemble data on the assets and liabilities of various types of financial intermediaries using the Federal Reserve's Financial Accounts of the United States (formerly the Flow of Funds Accounts). We examine data on commercial banks, property and casualty (P\&C) insurers, life insurers, money market funds (MMFs), government sponsored enterprises (GSEs), finance companies, real estate investment trusts (REITs), and security broker-dealers. We use data on intermediary balance sheets as of 2012Q4. However, the findings of our analysis do not depend significantly on when we look at the data.

In an effort to avoid subjective judgments, wherever possible we assign numerical values for $I_{L L I Q U I D}$, MATURITY $_{j}$, and $S T I C K Y_{j}$ based on the bank liquidity requirements put forth under Basel III. Specifically, for each instrument type, we attempt to choose values of these parameters based on the proposed calibration of Basel III's Net Stable Funding Requirement (NSFR) in Basel Committee on Banking Supervision (2010) and the final calibration of the Liquidity Coverage Ratio (LCR) in Basel Committee on Banking Supervision (2013), hereafter BCBS (2010 and 2013). However, we do need to apply some judgment in mapping the instrument types considered by Basel III to our aggregated Financial Accounts data. We also need to assign values for liability types issued by non-banks that are not considered by BCBS. As we detail in Appendix B, we have made every attempt to do so in the spirit of BCBS (2010 and 2013) and consistent with empirical evidence. The most important auxiliary assumption we make is that the policy-related liabilities of life insurers are quite sticky whereas those of P\&C insurers are somewhat less sticky. ${ }^{15}$

Consider first our ILLIQUID index for assets. We associate ILLIQUID with the parameter $\varphi_{i}$ in the model. We assign ILLIQUID $=0$ for US Treasuries, ILLIQUID $=0.15$ for GSE-backed MBS,

\footnotetext{
${ }^{15}$ See Bai, Krishnamurthy, and Weymuller (2013) for a similar, albeit more sophisticated, approach that requires more granular balance sheet data than is available in the Financial Accounts. Specifically, they use measures of asset illiquidity based on repo haircuts.
} 
$I L L I Q U I D=0.5$ for corporate equities, ILLIQUID $=0.75$ for consumer debt and home mortgages, and ILLIQUID = 1 for unsecured (C\&I) and secured commercial real estate (CRE) loans.

Next, consider our STICKY and MATURITY indices for liabilities. Starting with bank deposits, we assign STICKY $=0.7$ and MATURITY $=0.1$ for wholesale bank deposits, STICKY $=0.8$ and $M A T U R I T Y=0$ for retail time and savings deposits, and STICKY $=0.9$ and MATURITY $=0$ for transactions deposits. Turning to non-deposit liabilities, we assign STICKY $=0.6$ and MATURITY = 0.6 for corporate bonds and STICKY $=0$ and MATURITY $=0$ for non-deposit, short-term funding. For insurance policy liabilities, we assume STICKY $=$ MATURITY $=0.9$ for life policies and STICKY $=$ MATURITY $=0.6$ for $\mathrm{P} \& \mathrm{C}$ policies.

\section{Empirical tests}

\section{C.1 The cross-section of asset classes}

Prediction 1 says that traditional banks should hold a higher market share in more illiquid assets. A simple way to assess this prediction is to compute banks' market share for each asset type

$$
B A N K_{-} S H R_{i}=A_{b a n k, i} / \sum_{j} A_{j i} .
$$

In other words, for each asset type, we compute banks' share of the total amount of assets held by financial intermediaries. ${ }^{16}$ Since $B A N K \_S H R_{i}$ corresponds precisely to $\left(1-\mu_{i}\right)$ in the model and $I L L I Q U I D_{i}$ corresponds to $\varphi_{i}$, we should see a strong positive relationship between BANK_SHR $R_{i}$ on ILLIQUID $i$ in the cross-section of asset types.

Panel A of Figure 3 shows the result. The estimated regression is

$$
\text { BANK_SHR }=0.04+\underset{(t=3.47)}{0.57} \times I L L I Q U I D_{i}, \quad R^{2}=0.47
$$

As predicted, there is a strong positive relationship between asset illiquidity and banks' market share. Of course, this is just a descriptive cross-sectional regression with 12 observations. It is also a univariate regression, whereas our theory suggests a bivariate relationship: banks’ market share of a given asset should depend on both the asset's illiquidity and its fundamental safety. If the two characteristics are correlated-as they likely are-then (18) suffers from an omitted variable bias. To address this concern, we run a multivariate regression of banks' market share on asset illiquidity and fundamental safety, expecting positive coefficients on both. To run this multivariate regression,

\footnotetext{
${ }^{16}$ Specifically, we compute the share of assets held by the Financial Business sector in table L.107 that is attributable to U.S.-Chartered Depository Institutions in table L.110.
} 
we create a new variable called FUNDSAFE, which we set equal to 0.5 for equity-like exposures, 0.8 for risky debt exposures, and 1 for super-safe debt exposures. While this is solely meant to be illustrative, this approach yields

$$
B A N K_{-} S H R_{i}=-0.96+\underset{(t=5.80)}{0.78} \times I L L I Q U I D_{i}+\underset{(t=7.40)}{1.11} \times F^{\prime} U N D S A F E_{i}, \quad R^{2}=0.78 .
$$

The coefficient on $I L L I Q U I D_{i}$ is larger in the multivariate regression and the $R^{2}$ rises considerably. Alternatively, we can go back to running a univariate regression of banks' market share on illiquidity alone, simply dropping those asset classes with significantly greater fundamental cashflow risk. For instance, if we drop equity-like instruments (corporate equities and mutual fund shares), the $R^{2}$ in the univariate regression rises from 0.47 to 0.59 .

Turning to Prediction 2, other intermediaries besides traditional banks may also have stable funding and thus may also have a comparative advantage at holding illiquid assets. To capture this we compute the average funding stability of holders of a given asset as

$$
A V_{-} \operatorname{STICKY}_{i}=\frac{\sum_{j} A_{j i} \times L_{-} \operatorname{STICKY}_{j}}{\sum_{j} A_{j i}} .
$$

Since $A V \_S T I C K Y_{i}$ is a generalized version of $\left(1-\mu_{i}\right)$ in the model and $I L L I Q U I D_{i}$ corresponds to $\varphi_{i}$, Prediction 2 suggests that we should observe a strong positive relationship between the two in the cross-section. This is shown in Panel B of Figure 3 where we plot AV_STICKY $Y_{i}$ versus ILLIQUID . The estimated regression is given by

$$
A V_{-} \operatorname{STICKY}_{i}=0.59+\underset{(t=3.40)}{0.23} \times I L L I Q U I D_{i}, \quad R^{2}=0.41
$$

Again, we see a strong positive relationship. The $R^{2}$ of this regression rises from 0.41 to 0.64 if we exclude corporate equities and mutual fund shares.

Figure 3 confirms the core message of our model. Banks hold virtually no Treasuries despite their extreme safety. Treasuries are not exposed to interim fire-sale risk, so they are not profitable enough for banks. By contrast, banks are significant holders of GSE-backed MBS. These securities have limited downside risk, so banks can use them to back nearly as much safe short-term debt as a shadow bank. At the same time, GSE-backed MBS are more exposed to fire-sale risk than Treasuries, which makes them more attractive to traditional banks.

Figure 3 also shows that banks have a dominant market share in illiquid home mortgage loans, holding approximately $76 \%$ of unsecuritized whole loans. Banks are also the largest holders 
of illiquid commercial and multi-family home mortgages. Going beyond Figure 3, even within the category of home mortgages, banks tend to hold less "plain-vanilla” products, for which liquidation costs are likely higher. Specifically, banks are the dominant holders of second-lien home equity loans and other mortgage products falling outside of the conventional mortgage markets supported by the GSEs. ${ }^{17}$

Finally, Figure 3 shows that banks remain significant holders of unsecured loans to firms, holding $48 \%$ of all C\&I loans. As with home mortgages, when one looks within the category of C\&I loans, banks seem to specialize in those that are the most illiquid. For instance, banks have been steadily losing market share in the market for C\&I loans to large firms, which has become increasingly liquid in recent decades. At the same time, banks remain the near exclusive providers of C\&I loans to small- and medium-sized firms, which continue to be highly illiquid. According to the 2012Q4 Financial Accounts, banks hold 37\% of C\&I loans to non-financial corporations, but 86\% of C\&I loans to non-financial non-corporate businesses, which tend to be much smaller.

\section{C.2 The cross-section of intermediary types}

Prediction 4 suggests that in the cross-section of intermediary types we should see a strong positive relationship between $A \_I L L I Q U I D_{j}$ and $L \_S T I C K Y_{j}$. Since the stickiness of liabilities as opposed to their contractual maturity is the key to avoiding costly liquidations, we expect to see weaker relationship between $A \_I L L I Q U I D_{j}$ and $L \_M A T U R I T Y_{j}$. In particular, we expect traditional banks to look like an extreme outlier in this regard because their assets are highly illiquid given the short contractual maturity of their liabilities.

Panel A of Figure 4 plots $A \_I L L I Q U I D_{j}$ versus $L \_S T I C K Y_{j}$. As predicted by the theory, we see a strong positive relationship and the estimated regression is

$$
A_{-} I L L I Q U I D_{j}=0.13+\underset{(t=5.02)}{0.55} \times L_{-} S_{S T I C K Y}, \quad R^{2}=0.64 .
$$

Panel B of Figure 4 plots $A \_I L L I Q U I D_{j}$ versus $L_{-} M A T U R I T Y_{j}$. The estimated regression is

$$
A_{-} I L L I Q U I D_{j}=0.27+\underset{(t=1.59)}{0.36} \times L_{-} \text {MATURITY }_{j}, \quad R^{2}=0.29 \text {, }
$$

So, as expected, the regression fit deteriorates significantly from Panel A to Panel B. Although there is a general tendency for intermediaries with longer maturity liabilities hold more illiquid assets,

\footnotetext{
${ }^{17}$ For instance, according to the Financial Accounts, commercial banks held $85 \%$ of the $\$ 750$ billion in second-lien home mortgages loans as of 2012Q4.
} 
banks are a significant outlier. Relative to other patient investors, who obtain stable funding by issuing liabilities with long contractual maturities, banks issue short-term liabilities but organize themselves in such a way that their contractually short-term deposits are de facto extremely stable.

\section{Related micro evidence}

While we have focused on the aggregate structure of financial intermediation, the banking literature contains some complementary micro evidence also consistent with our theory. Using the Survey of Terms of Business Lending, Berlin and Mester (1999) find that, in the cross-section of banks, those with greater access to sticky “core” deposits (i.e., transaction and saving deposits) are more likely to form stable lending relationships with firms, thereby providing borrowers with insurance against transitory market shocks. Black, Hancock, and Passmore (2007 and 2010) find that banks with a large supply of core deposits tend to specialize in more illiquid informationintensive loans, whereas banks which are more reliant on wholesale funding tend to specialize in easy-to-value loans. $^{18}$

\section{Discussion}

The model may help shed some light on the accounting practices of traditional banks and market-based intermediaries. Broker-dealers, bank trading departments, mutual funds, and hedge funds, all of which typically lack access to stable short-term funding, operate on a mark-to-market accounting basis. This means that, even if a decline in security prices is temporary and driven by non-fundamental factors, it impacts their accounting earnings. In contrast, accounting conventions for banks shield their earnings from transitory changes in the unrealized market value of loans or securities. These "temporary impairments" flow through another liability account called “accumulated other comprehensive income” and only impact reported earnings if the gains or losses are realized by selling the security.

If one adopts the traditional view that movements in asset prices are driven entirely by fundamental news about future cash flows, then banks' accounting practices seem perplexing. However, to the extent that asset price movements are driven by non-fundamental shocks and

\footnotetext{
${ }^{18}$ Black, Hancock, and Passmore (2007) show that there is strong positive association between core deposit taking and small business lending, while Black, Hancock, and Passmore (2010) find an similar connection between core deposits and information-intensive (i.e., subprime) mortgage lending.
} 
banks' stable funding structures enable them to ride out such transient shocks, then there may be some logic to these accounting practices. ${ }^{19}$

The model may also have something to say about the bricks-and-mortar costs associated with bank deposit-taking. We have estimated these costs to be quite high, averaging on the order of 1.30 percent of deposits over the period from 1984 to 2012. These costs ultimately represent a choice-banks could always choose to offer their customers fewer and less attractive branch locations, fewer opportunities for interacting with a human teller, and so forth. One view is that these amenities are simply a separable flow of services to depositors, conceptually analogous to paying more interest. However, an interesting alternative is that they represent a deliberate effort to build loyalty by creating a form of switching costs. By contrast, a money market fund complexwhich also takes deposits, but which invests exclusively in short-term assets-has less reason to spend as heavily on a branch network.

\section{Normative Implications}

A central set of issues in current discussions of financial regulation concerns the migration of intermediation activity from the traditional banking sector to the shadow banking sector. While our model has some interesting normative implications, it is not well-suited for performing a complete and balanced policy analysis. Given the nature of the cash-flow uncertainty that we have assumed, the deck is stacked, from a normative perspective, against the shadow banking sector. This is so because the worst-case scenario outcome of $z_{i}$ is not so bad for the kinds of assets that traditional banks hold, which means that they can create completely safe claims without ever exposing a government deposit insurer to any risk of loss. In a more realistic model, with an extremely adverse state of the world that would more than wipe out all bank capital, creating safe traditional bank claims would inevitably expose taxpayers to some tail risk. This could be socially costly to the extent that deposit insurance creates moral hazard problems, government fiscal capacity is limited, or traditional banks do not fully understand tail risks (see Gennaioli et al 2012 and 2013).

In contrast to traditional banking, shadow banking does create negative externalities in our model, as the social costs of fire sales exceed the private costs (Stein 2012). This is because the ability of shadow banks to create money-like claims is constrained by the time- 1 liquidation value

\footnotetext{
${ }^{19}$ See Cochrane (2011) for a related discussion.
} 
of their collateral. An intermediary that switches from traditional to shadow banking fails to internalize how this switch reduces liquidation prices and, thus, the feasible amount of money creation by other shadow banks-i.e., there is a pecuniary externality. As a consequence, in the private-market equilibrium the shadow banking sector is too large and the traditional banking sector is too small, compared to the social optimum. A regulator wishing to restore the social optimum can do so by imposing a set of minimum required haircuts on shadow banks, in an effort push money creation back to traditional banks. These regulatory haircuts are effectively an extra capital requirement that the shadow banking sector must set aside when raising short-term funding against risky assets, above and beyond what the private sector demands simply to make the short-term claims safe. Specifically, a regulator imposing an additional haircut of $h_{i}$ only allows shadow banks to create $\left(k_{i}-h_{i}\right) F_{i}<k_{i} F_{i}$ of safe claims using the risky asset $i$ as collateral. These haircuts function as a Pigouvian tax on the fire-sale externality associated with the shadow-banking sector.

In the Appendix, we show that these optimal shadow-banking haircuts, denoted by $h_{i}^{* *}$, have a simple and intuitive form:

$$
h_{i}^{* *}=\gamma \frac{\varepsilon\left(\varphi_{i}\right)}{1-\varepsilon\left(\varphi_{i}\right)} \frac{z_{i}}{F_{i}} .
$$

Here $\varepsilon\left(\varphi_{i}\right)$ denotes the elasticity of the fire-sale discount with respect to liquidation volume and $\varepsilon\left(\varphi_{i}\right)$ is an increasing function of asset illiquidity $\varphi_{i}$. Thus optimal haircut requirements depend on three factors. First, the required haircut is larger for more illiquid assets. This is natural since $\varepsilon\left(\varphi_{i}\right)$ captures the severity of the pecuniary externality created by fire-sale liquidations-i.e., the strength of the over-migration tendency. Second, the optimal haircut is higher for assets with high values of $z_{i}$-i.e., for assets with little fundamental risk. These are the assets where traditional banks' stable, hold-to-maturity strategy can create the most monetary services. And, by assumption in our model, traditional banking is a socially costless technology for creating private money. So one wants to lean most aggressively against shadow banking in the cases where traditional banks provide an efficient alternative. ${ }^{20}$ Finally, the required haircut on all assets needs to be larger when the demand

\footnotetext{
${ }^{20}$ For example, our model implies that $h_{i}^{* *}=0$ for equity-like assets where $z_{i}=0$-in other words, there is no need for regulation in this case. This is because when $z_{i}=0$, shadow banking is the only technology for creating money-like claims, so there is no scope for over-migration. However, when $z_{i}>0$, there is also a stable banking technology (which is socially costless by assumption) to migrate away from.
} 
for monetary services, $\gamma$, is larger. The intuition is that the private temptation to create money-like claims using the unstable shadow banking technology is greater when money demand is high.

Again, however, we reiterate the caveat: while the formula for the optimal haircut $h_{i}^{* *}$ captures some interesting and economically relevant effects, it represents only one side of what in the real world is a more complex tradeoff. A more complete normative analysis would introduce costs of over-relying on a government-backstopped traditional banking sector. The effects that we have identified would continue to show up in such a richer model, and would still have something useful to say about cross-sectional differences in optimal shadow-banking haircuts across assets.

\section{Conclusion}

We have argued that the specialness of traditional banks comes from combining stable money creation on the liability side with assets that have relatively safe long-run cash flows but possibly volatile market values and limited liquidity. To make this business model work, banks rely on deposit insurance, and bear the associated costs of capital regulation.

Some preliminary evidence is consistent with the predictions of our model. In the crosssection of fixed income assets, the most illiquid assets have the highest share held by commercial banks. As the model predicts, banks specialize in holding relatively safe fixed income assets but are not afraid of illiquidity. In a cross-section of types of financial intermediaries, intermediaries with stickier liabilities hold less liquid assets. Banks, in particular, appear as having extremely sticky liabilities, as well as very illiquid assets. More casual evidence, such as the near absence of both Treasuries and equities in bank asset portfolios, also supports our view.

One key message of the paper is that the structure of financial intermediation may be shaped in important ways by the sorts of non-fundamental movements in asset prices-due to fire sales, noise trading, slow-moving capital, and other frictions - that have been so extensively documented in the asset-pricing literature. Specifically, one central role of intermediaries-and of banks in particular-is to act as a bridge between households who want to put their money in a safe place they do not need to watch, and securities markets where even assets with relatively low fundamental risk can have volatile market prices. 


\section{References}

Bai, Jennie, Arvind Krishnamurthy, and Charles-HenriWeymuller (2013), "Measuring Liquidity Mismatch in the Banking Sector,” Northwestern University working paper.

Basel Committee on Banking Supervision (2010) http://www.bis.org/publ/bcbs188.pdf.

Basel Committee on Banking Supervision (2013) http://www.bis.org/publ/bcbs238.pdf.

Berlin, Mitchell and Loretta J. Mester (1999) “Deposits and Relationship Lending” Review of Financial Studies 12(3): 579-607.

Bernanke, Ben S. (2005) “The Global Saving Glut and the U.S. Current Account Deficit," http://www.federalreserve.gov/boarddocs/speeches/2005/200503102/.

Black, Lamont K., Diana Hancock, and Wayne Passmore (2007) "Bank Core Deposits and the Mitigation of Monetary Policy,” Federal Reserve Board of Governors, FEDS working paper 2007-65.

Black, Lamont K., Diana Hancock, and Wayne Passmore (2010) “The Bank Lending Channel of Monetary Policy and Its Effect on Mortgage Lending," Federal Reserve Board of Governors, FEDS working paper 2010-39.

Board of Governors of the Federal Reserve System (1943) Banking and Monetary Statistics, 19191941. Washington: Publications Services of the Board of Governors. Washington, DC.

Board of Governors of the Federal Reserve System (1959) All Bank Statistics, United States, 18961955. Washington: Publications Services of the Board of Governors. Washington, DC.

Brunnermeier, Markus K., Gary Gorton, Arvind Krishnamurthy (2011) "Risk Topography,” NBER Macroeconomics Annual 2011, Volume 26, pages 149-176.

Brunnermeier, Markus K., Gorton Gary, and Krishnamurthy Arvind (2013) "Liquidity Mismatch,” in Risk Topography, Chicago, (In Press)

Brunnermeier, Markus K., and Lasse Pedersen (2009) "Market Liquidity and Funding Liquidity," Review of Financial Studies 22(6): 2201-2238.

Caballero, Ricardo J. and Emmanuel Farhi (2013). “A Model of the Safe Asset Mechanism (SAM): Safety Traps and Economic Policy,” NBER Working Paper 18737.

Chernenko, Sergey, and Adi Sunderam (2013) "Frictions in Shadow Banking: Evidence from the Lending Behavior of Money Market Funds,” forthcoming Review of Financial Studies.

Cochrane, John H. (2011) “Discount Rates” Journal of Finance 66(4): 1047-1108.

Coval, Joshua, Jakub Jurek, and Erik Stafford (2009a) “Economic Catastrophe Bonds,” American Economic Review 99(3): 628-666.

Coval, Joshua, Jakub Jurek, and Erik Stafford (2009b) “The Economics of Structured Finance,” Journal of Economic Perspectives 23(1): 3-25

Dang, Tri Vi, Gary Gorton, and Bengt Holmström (2013) "Ignorance, Debt and Financial Crises,” Columbia University working paper.

DeAngelo, Harry and Rene M. Stulz (2013) "Why High Leverage is Optimal for Banks," Fisher College of Business Working Paper No. 2013-03-08.

DeLong, J. Bradford, Andrei Shleifer, Lawrence H. Summers, and Robert J. Waldmann. 1990. 
“Noise Trader Risk in Financial Markets,” Journal of Political Economy, 98(4): 703-38.

Diamond, Douglas W. (1984) “Financial Intermediation and Delegated Monitoring,” Review of Economic Studies, 51(3): 393-414.

Diamond, Douglas W. (1997), “Liquidity, Banks, and Markets,” Journal of Political Economy 105(5): 928-956.

Diamond, Douglas W. and Philip Dybvig (1983) "Bank Runs, Deposit Insurance, and Liquidity," Journal of Political Economy. 91(3): 401-419.

Diamond Douglas W. and Raghuram G. Rajan (2001) "Liquidity Risk, Liquidity Creation and Financial Fragility: A Theory of Banking,” Journal of Political Economy, 109(2): 287-327.

English , William B., Skander J. Van den Heuvel, and Egon Zakrajsek (2012) "Interest Rate Risk and Bank Equity Valuations,” Federal Reserve Board of Governors, FEDS working paper 2012-26.

Gennaioli, Nicola, Andrei Shleifer, and Robert W. Vishny (2012) “Neglected Risks, Financial Innovation, and Financial Fragility,” Journal of Financial Economics 104(3): 452-468.

Gennaioli, Nicola, Andrei Shleifer, and Robert W. Vishny (2013). “A Model of Shadow Banking,” Journal of Finance 68(4): 1331-1363.

Gorton, Gary, and Andrew Metrick (2010) “Regulating the Shadow Banking System,” Brookings Papers on Economic Activity 41: 261-312.

Gorton, Gary, and Andrew Metrick (2011) “Securitized Banking and the Run on Repo,” Journal of Financial Economics 104(3): 425-451.

Gorton, Gary, and Guillermo Ordoñez (2014) "Collateral Crises," American Economic Review, 104(2): 343-78.

Gorton, Gary and George Pennacchi (1990), "Financial Intermediaries and Liquidity Creation," Journal of Finance 45(1): 49-71.

Gourinchas, Pierre-Olivier and Olivier Jeanne (2012) “Global Safe Assets,” BIS Working Paper 399.

Holmström, Bengt and Jean Tirole (1997) “Financial Intermediation, Loanable Funds, and the Real Sector,” Quarterly Journal of Economics 112 (3): 663-691.

Holmström, Bengt and Jean Tirole (2011) Inside and Outside Liquidity, Cambridge: MIT Press.

Hughes, Joseph P. and Loretta J. Mester (2010) "Efficiency in Banking: Theory, Practice and Evidence,” in The Oxford Handbook of Banking, Oxford University Press: Oxford, UK, edited by Allen Berger, Philip Molyneux, and John Wilson, 463-485.

Jacklin, Charles J. (1987) “Demand Deposits, Trading Restrictions, and Risk Sharing,” In Contractual Arrangements for Intertemporal Trade, edited by Edward C. Prescott and Neil Wallace. Minneapolis: Univ. Minnesota Press, 1987.

Kacperczyk, Marcin and Philipp Schnabl (2013), “How Safe are Money Market Funds?,” Quarterly Journal of Economics 128(3), 1073-1122.

Kashyap Anil K., Raghuram G. Rajan, and Jeremy C. Stein (2002), “Banks as Liquidity Providers: an Explanation for the Co-existence of Lending and Deposit-Taking," Journal of Finance 57(1): 33-73. 
Krishnamurthy, Arvind, Stefan Nagel, and Dmitry Orlov (2013) “Sizing up Repo,” forthcoming Journal of Finance.

Krishnamurthy, Arvind and Annette Vissing-Jorgensen (2013) "Short-term Debt and Financial Crises: What We Can Learn From U.S. Treasury Supply,” Northwestern working paper.

Miller, Merton H. (1977) “Debt and Taxes,” Journal of Finance 32(2): 261-275.

Modigliani, Franco, and Merton H. Miller (1958) "The Cost of Capital, Corporation Finance and the Theory of Investmen,t” American Economic Review, 48(3): 261-97.

Moreira, Alan and Alexi Savov (2014) "The Macroeconomics of Shadow Banking,” New York University working paper.

Neumark, David and Steven A. Sharpe (1992) "Market Structure and the Nature of Price Rigidity: Evidence from the Market for Consumer Deposits," Quarterly Journal of Economics 107(2): 657680.

Pennacchi, George (2012) “Narrow Banking,” Annual Review of Financial Economics Vol. 4: 141159.

Shin, Hyun Song (2009) "Reflections on Northern Rock: The Bank Run that Heralded the Global Financial Crisis," Journal of Economic Perspectives 23(1): 101-120.

Shleifer, Andrei, and Robert W Vishny (1992) "Liquidation Values and Debt Capacity: A Market Equilibrium Approach,” Journal of Finance 47(4): 1343-1366.

Shleifer, Andrei, and Robert W. Vishny (1997) “The Limits of Arbitrage,” Journal of Finance 52, no. 1: 35-55

Shleifer, Andrei, and Robert W. Vishny (2010) "Unstable Banking," Journal of Financial Economics 97(3): 306-318.

Stein, Jeremy C. (2012) "Monetary Policy as Financial-Stability Regulation” Quarterly Journal of Economics 127(1): 57-95.

Sunderam, Adi (2013) "Money Creation and the Shadow Banking System,” Harvard University working paper.

Weymuller, Charles-Henri (2013) "Banks as Safety Multipliers: A Theory of Safe Assets Creation,” Harvard University working paper. 
Figure 1: Data on US Commercial Bank Balance Sheets, 1896-2012. This figure shows the evolution of the aggregate balance sheet of US commercial banks from 1896-2012. All figures are in book terms and are scaled by total assets. The series for 1896-1918 are based on data for "all banks” from All Bank Statistics, United States, 1896-1955. The series for 1919-1933 are based on Federal Reserve member banks from Banking and Monetary Statistics, 1919-1941. The series for 1934-2012 are based on all insured commercial banks from the FDIC's Historical Statistics on Banking available at http://www2.fdic.gov/hsob/.

Panel A: Bank liability composition

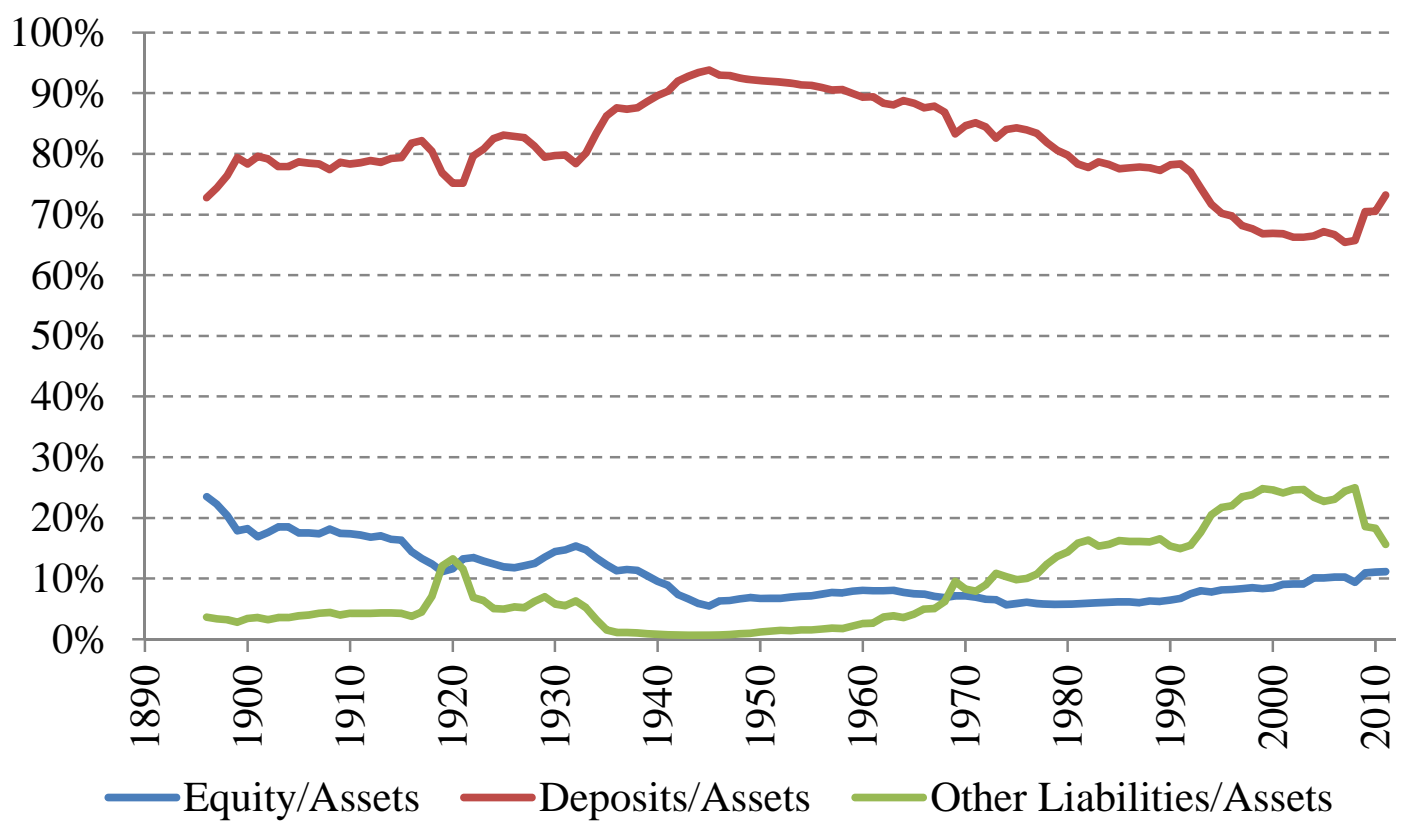

Panel B: Bank asset composition

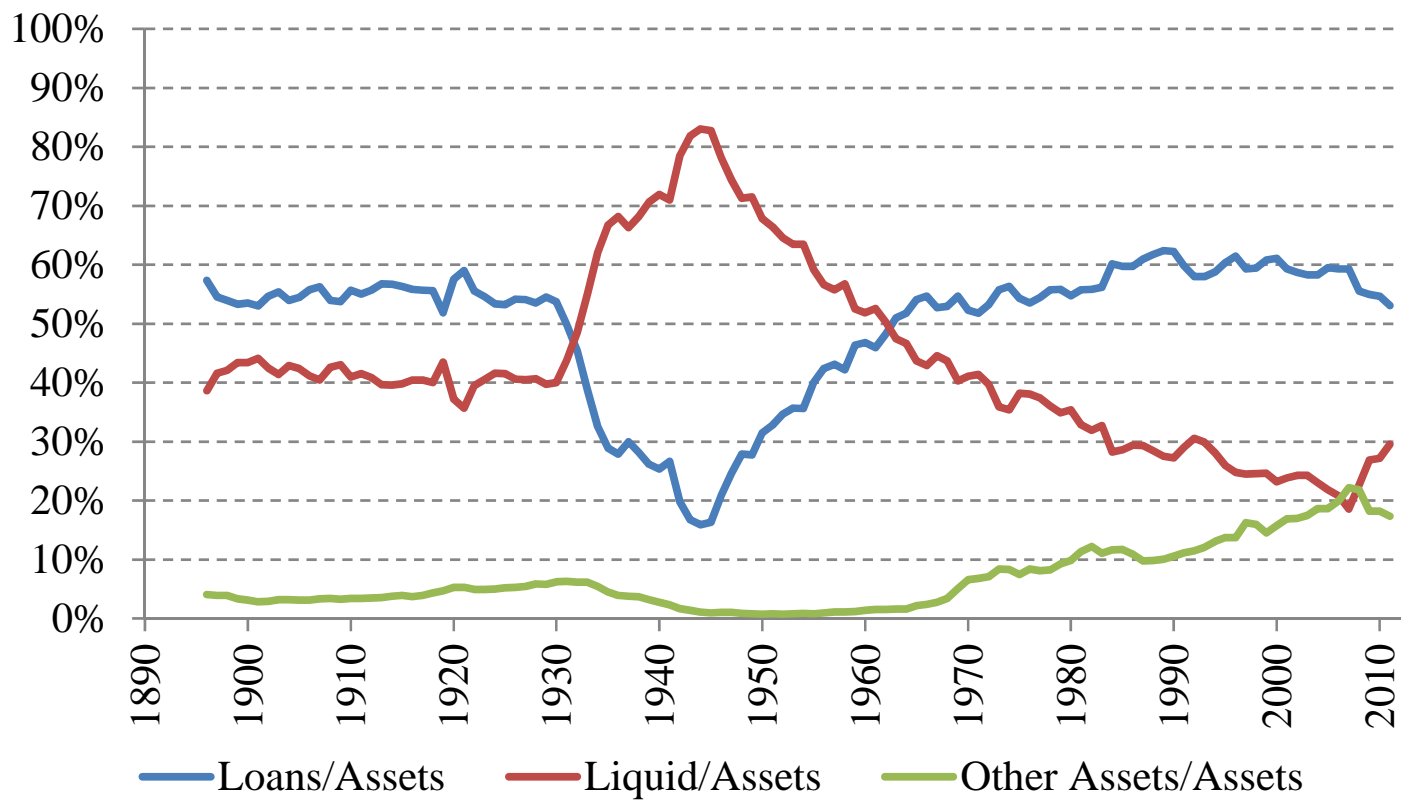


Figure 2: Composition of Bank Securities Portfolios, 1994-2012. This figure shows the composition of bank securities portfolios based on data from the Call Reports. We report bank holdings of various security types as a fraction of total bank investment securities (this excludes trading account assets). We restrict attention to banks with assets greater than \$1 billion. Panel A shows the value-weighted average securities portfolio for all banks. Panel B shows the securities portfolio of banks whose equity-to-assets ratio exceeds the industry median.

Panel A: Value-weighted averages for all banks

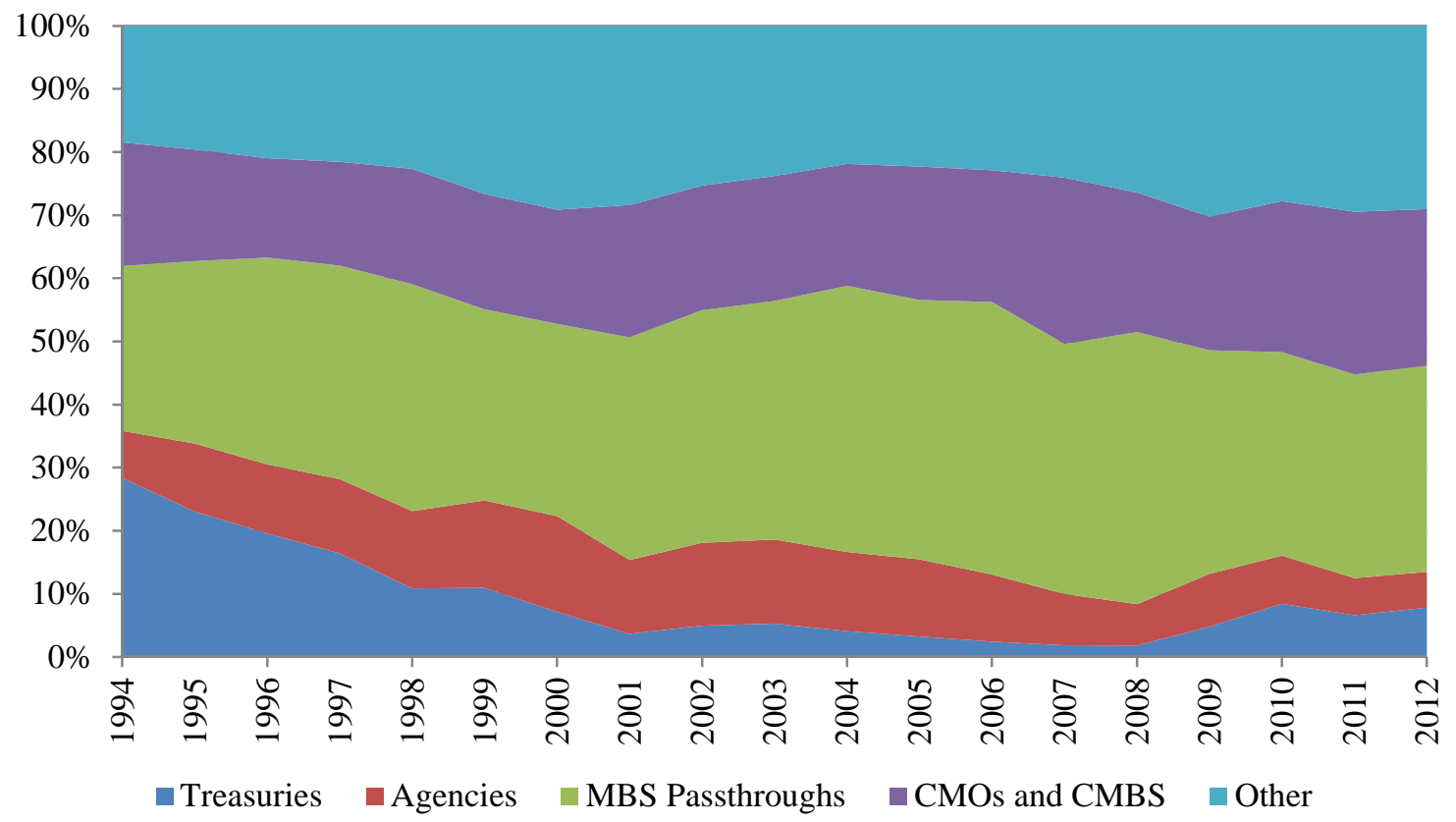

Panel B: Value-weighted averages for highly capitalized banks

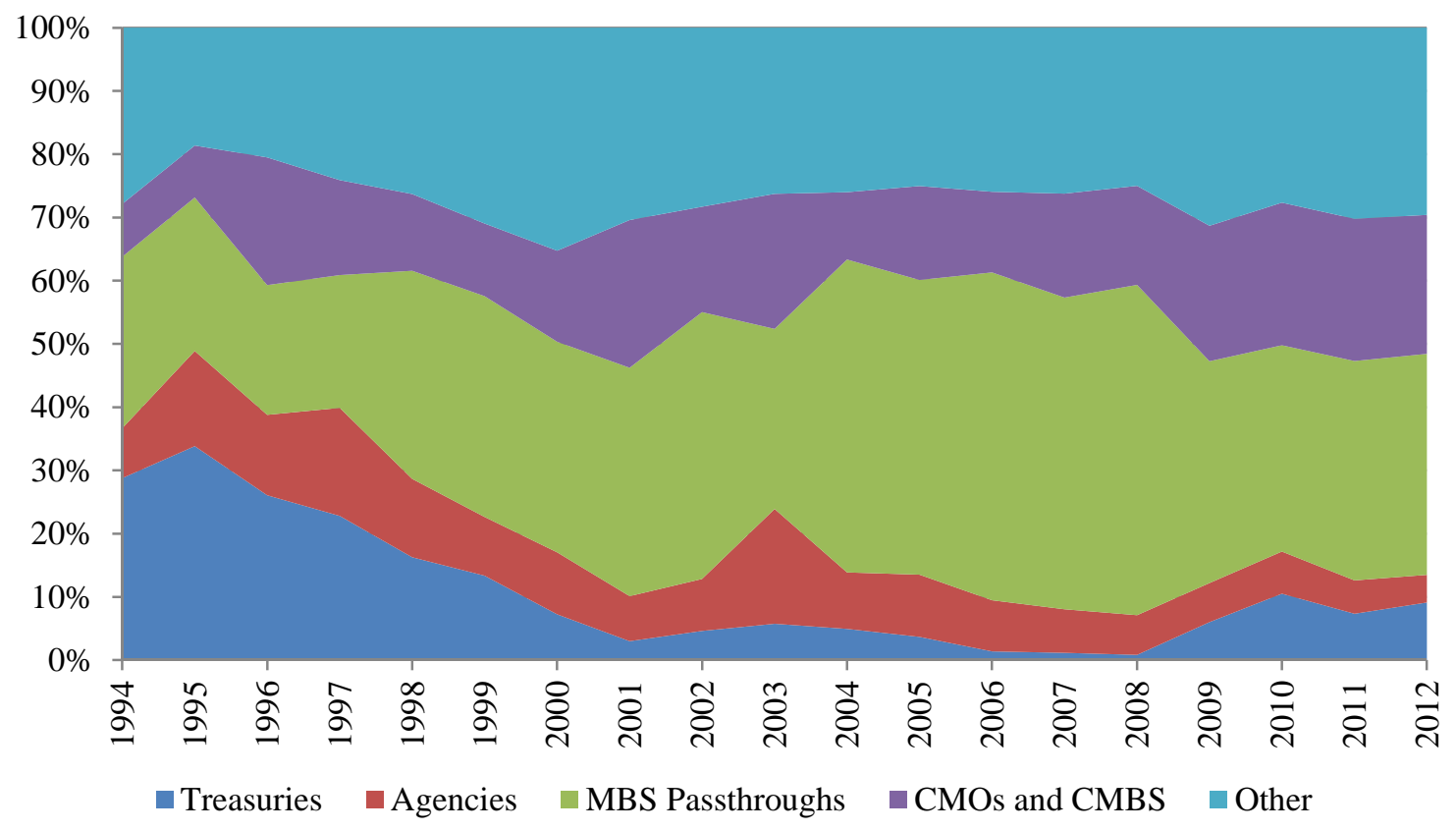


Figure 3: The Cross-Section of Asset Classes. Panel A plots BANK_SHR $R_{i}$ versus $I L L I Q U I D_{i}$ for major financial asset classes. Panel B plots $A V_{-} S T I C K Y_{i}$ verus $I L L I Q U I D_{i}$. The figures are based on data from the Financial Accounts of the United States as of 2012Q4 and information contained in BCBS (2010 and 2013). See the Appendix for further details.

Panel A: The Market Share of Commercial Banks versus Asset Illiquidity

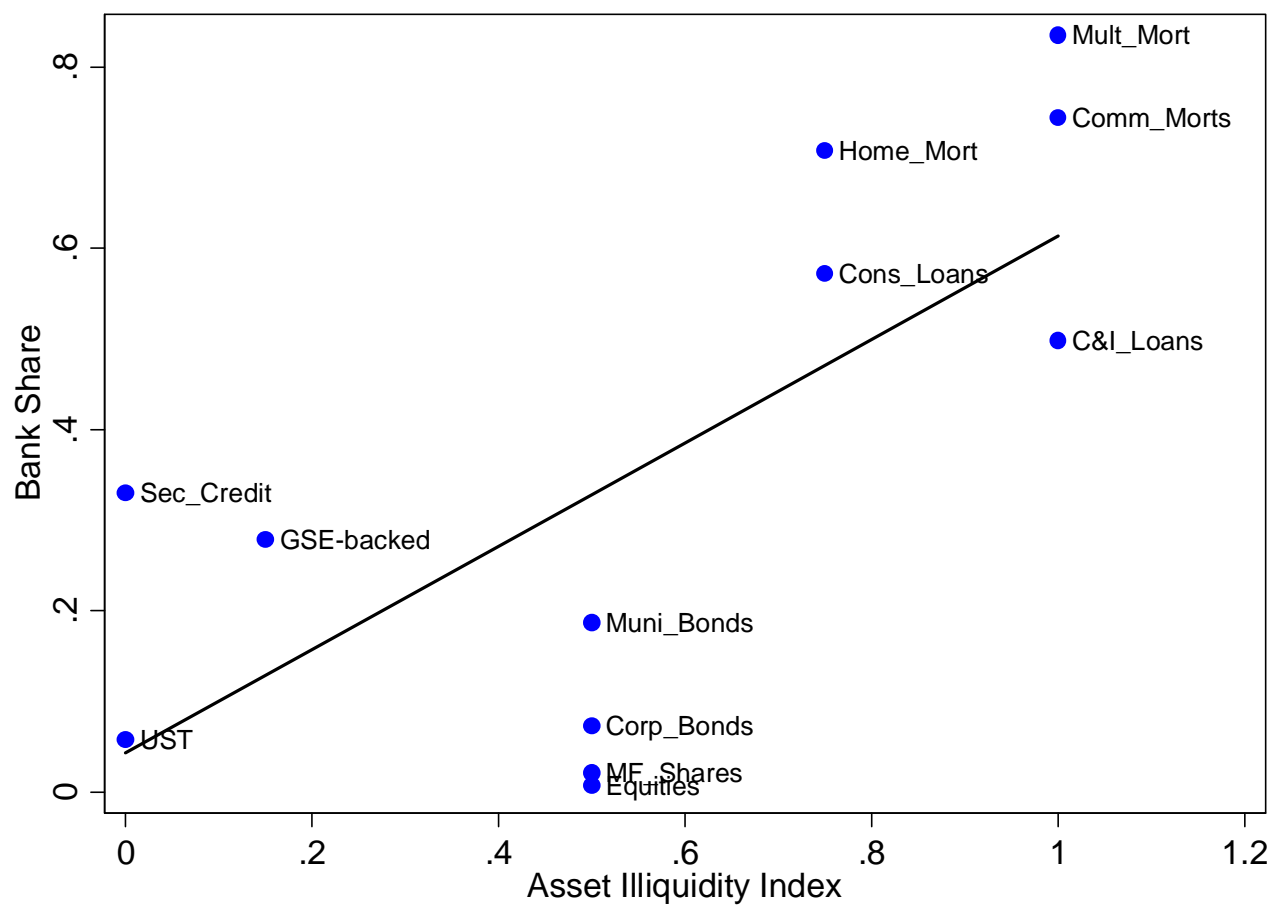

Panel B: The Average Liability Stickiness of Asset Holders versus Asset Illiquidity

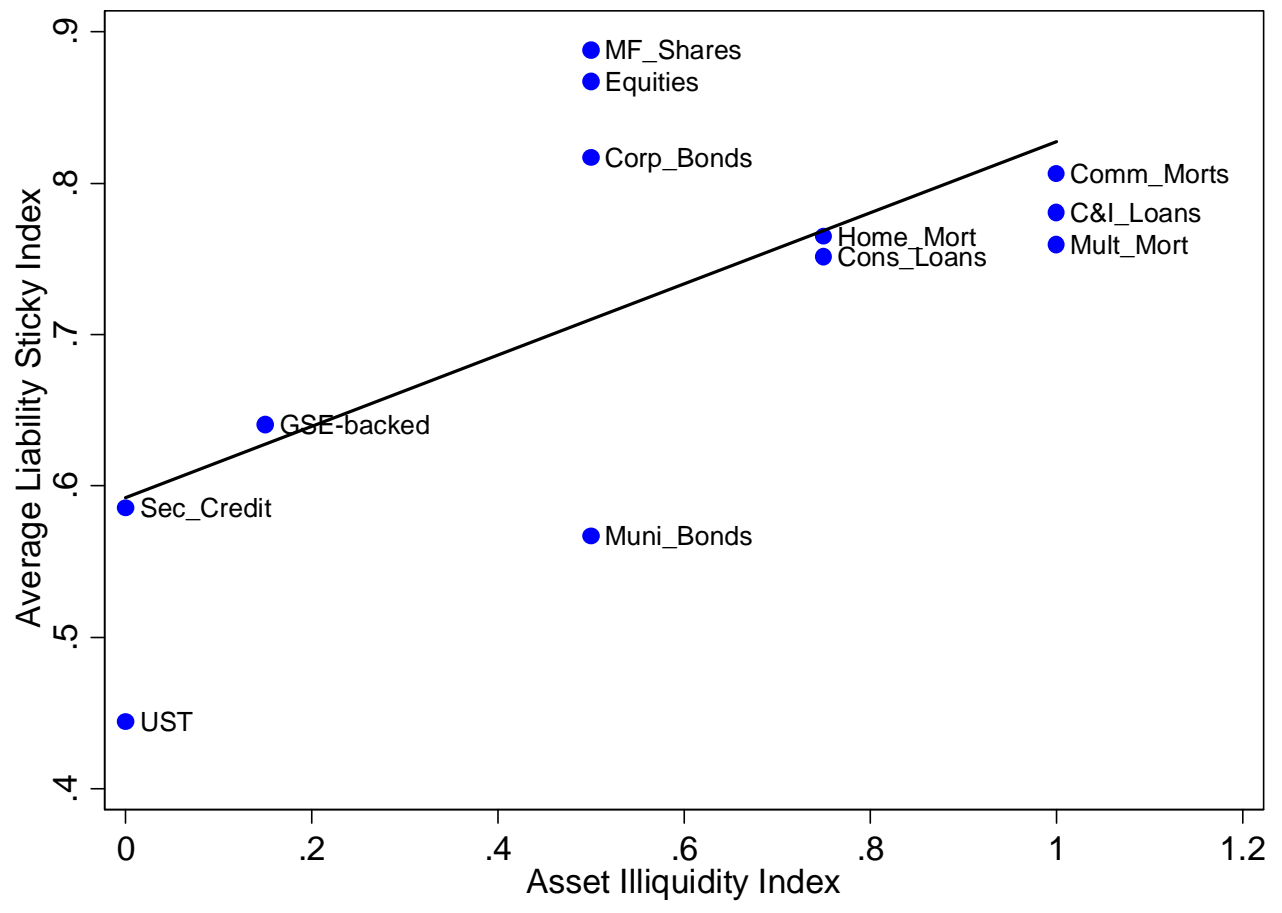


Figure 4: The Cross-Section of Intermediary Types. Panel A plots A_ILLIQUID $D_{j}$ versus $L \_S T I C K Y_{j}$ for different intermediary types. Panel B plots $A \_I L L I Q U I D_{j}$ versus $L \_M A T U R I T Y_{j}$. The figures are based on data from the Financial Accounts of the United States of as 2012Q4 and information contained BCBS (2010 and 2013). See the Appendix for further details.

Panel A: Intermediary Asset Illiquidity versus Liability Stickiness

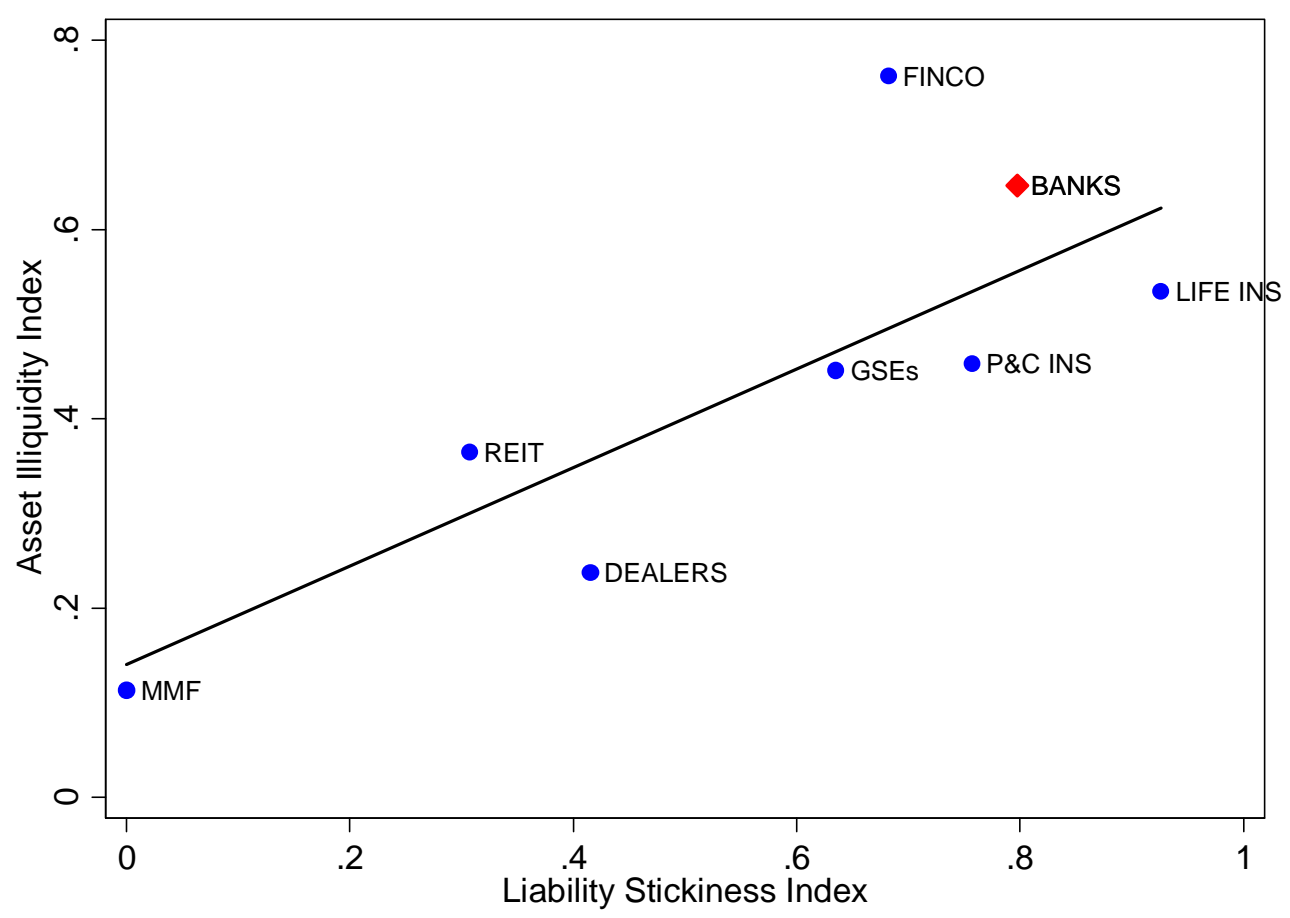

Panel B: Intermediary Asset Illiquidity versus Liability Contractual Maturity

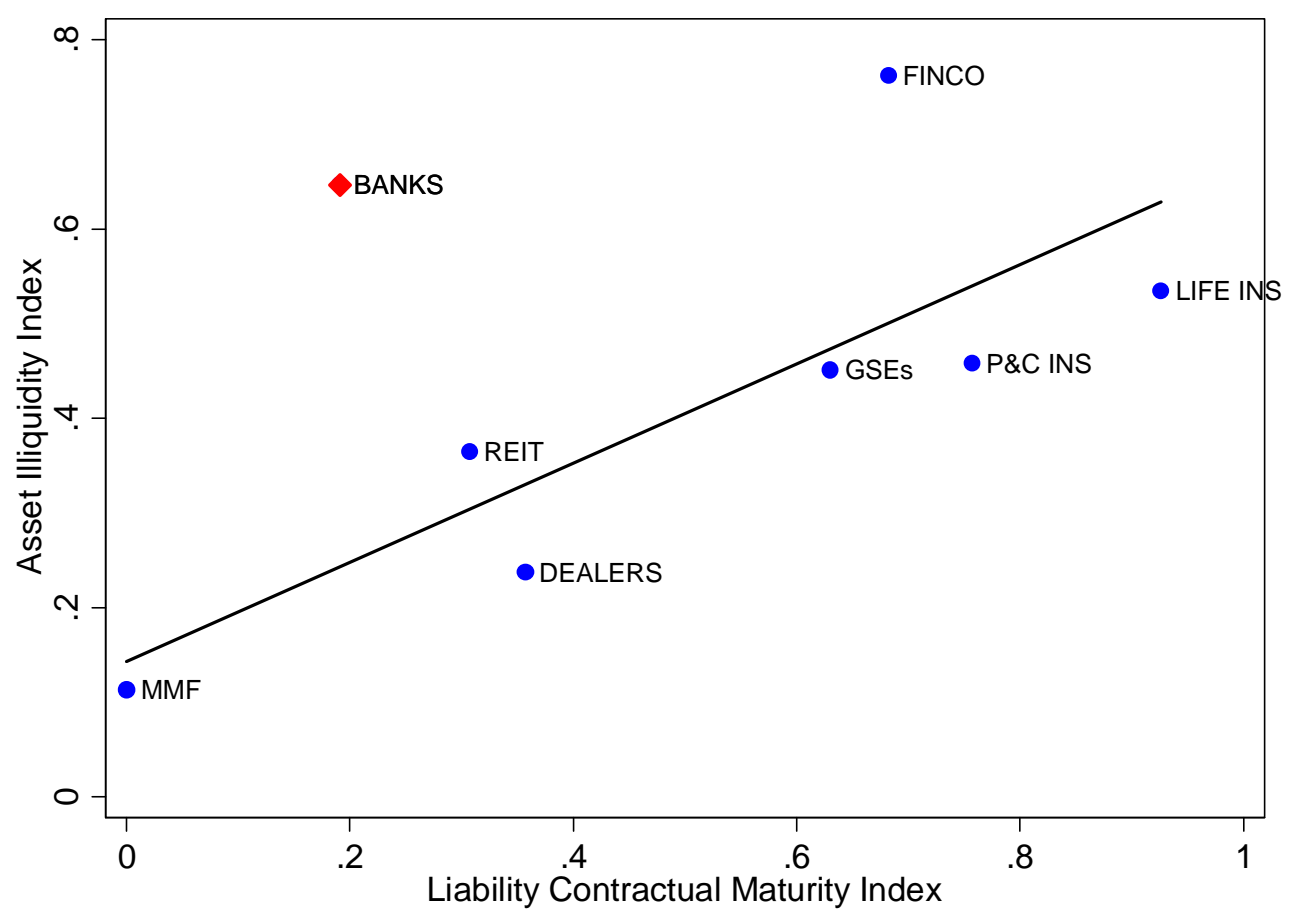


Table I: US Commercial Bank Balance Sheet Composition, 2012. This table illustrates the balance sheet composition of US commercial banks as of December 31, 2012 using Call Report data. We restrict attention to commercial banks with assets greater than $\$ 1$ billion. Collapsing all commercial banks owned by a single bank holding company into a single banking firm, our $\$ 1$ billion size cutoff leaves us with 501 banking firms as of year-end 2012. The table shows the valueweighted average balance sheet shares and (the equal weighted) $90^{\text {th }}$ and $10^{\text {th }}$ percentiles of bank balance sheet shares. Panel A shows results for all banks. Panel B shows results for highly capitalized banks whose equity-to-assets ratio exceeds the industry median.

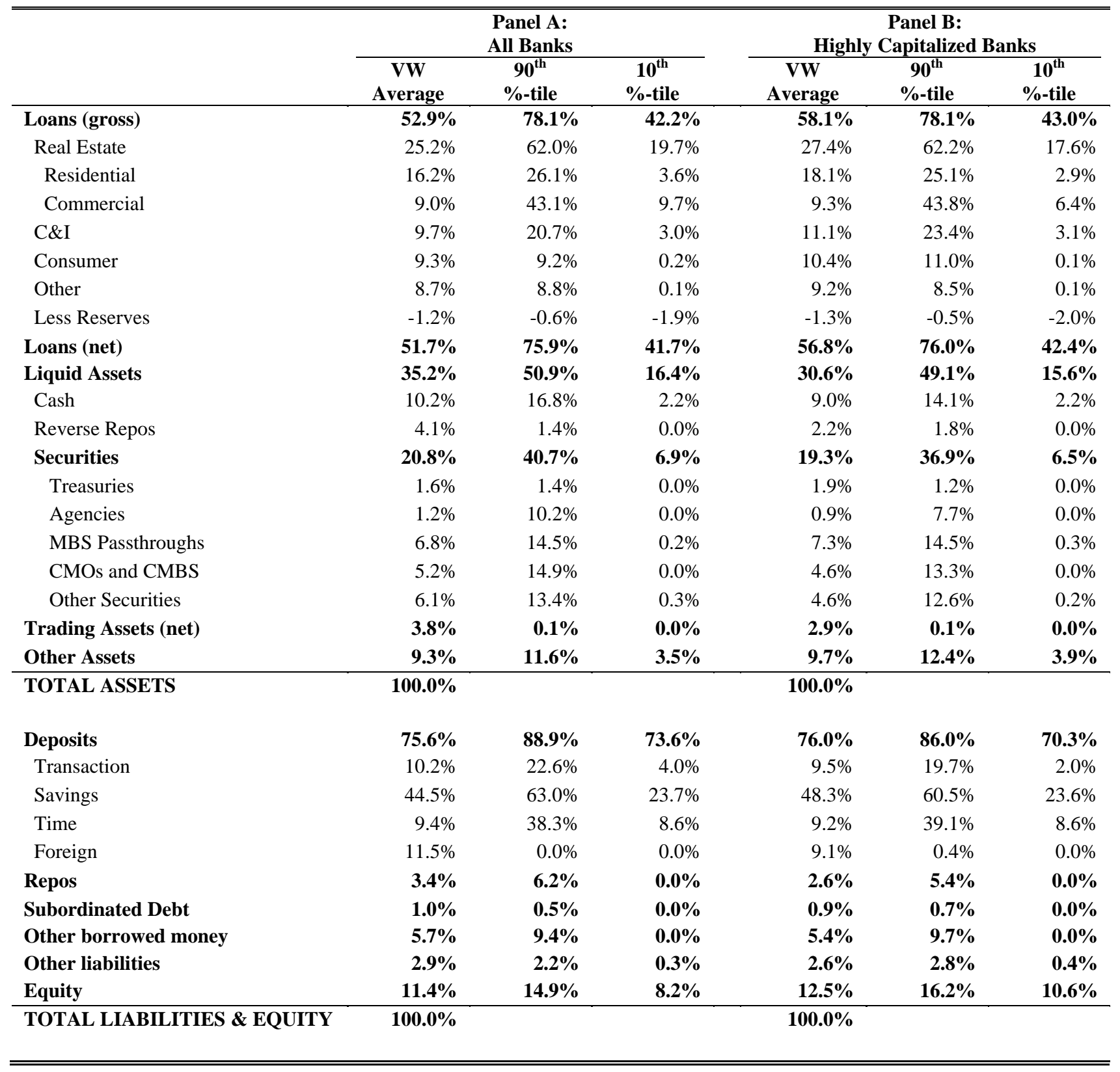




\section{Appendix}

\section{A. Estimating the Profitability of Narrow Banking}

We estimate the profitability of narrowing bank using

$$
\Pi=\left(R_{F}-R_{D E P}\right)+\frac{N O N I N T I N C}{D E P}-\frac{N O N I N T E X P}{D E P} .
$$

The text describes the computation of all the components of (A1) for the US commercial banking industry, except for the non-interest expense associated with deposit-taking NONINTEXP/DEP. This term is not directly available from Call Reports: banks report their total noninterest expense, but we are only interested in those expenses attributable to deposit-taking.

To get an estimate of the expenses associated with deposit taking, we adopt a simple hedonic approach. Specifically, each year we run a cross-sectional regression of NONINTEXP $P_{i t} / A S S E T_{i t}$ on asset shares, liability shares, and other controls:

$$
\frac{\operatorname{NONINTEXP}_{i t}}{\operatorname{ASSET}_{i t}}=\alpha_{t}+\sum_{k=1}^{K} \beta_{t}^{(k)} \cdot \frac{\operatorname{ASSET}_{i t}^{(k)}}{\operatorname{ASSET}_{i t}}+\sum_{j=1}^{J} \gamma_{t}^{(j)} \cdot \frac{\operatorname{DEPOSIT}_{i t}^{(j)}}{\operatorname{ASSET}_{i t}}+\boldsymbol{\theta}^{\prime} \mathbf{x}_{i t}+\varepsilon_{i t} .
$$

We choose the independent variables so that the intercept term for year $t, \alpha_{t}$, can be interpreted as the operating expenses associated with a "mutual-fund-like” bank that owns a portfolio of long-term marketable securities and finances these assets using only wholesale funding and equity. The slope coefficients in (A2) are interpretable as unit noninterest expenses associated with various activities.

We use cross-sectional variation in banks’ asset mix to identify the $\beta_{t}^{(k)}$. We control for real estate loans $\left(R E L O A N_{i t} / A S S E T_{i t}\right), \quad C \& I$ loans $\left(C I L O A N_{i t} / A S S E T_{i t}\right)$, consumer loans $\left(C O N L O A N_{i t} / A S S E T_{i t}\right)$, other loans $\left(O T H L O A N_{i t} / A S S E T_{i t}\right)$, and trading assets (TRADING $\left.{ }_{i t} / A S S E T_{i t}\right)$. Liquid assets (cash, interbank loans, and securities) and other assets are the omitted categories absorbed in $\alpha_{t}$. To identify the $\gamma_{t}^{(j)}$, we control for transaction deposits (TRANSDEPOSIT $T_{i t} / A S S E T_{i t}$ ), savings deposits (SAVEDEPOSIT $T_{i t} /$ ASSET $_{i t}$ ), and foreign deposits (FORDEPOSIT $\left.T_{i t} / A S S E T_{i t}\right)$. Time deposits and other borrowed money are the omitted liability categories that are absorbed in $\alpha_{t}$. Finally, we control for bank size $\left(\ln \left(A S S E T_{i t}\right)\right)$ and noninterest income not associated with deposittaking or credit intermediation (OTHNONINTIC ${ }_{i t} /$ ASSET $\left._{i t}\right)^{21}$

\footnotetext{
${ }^{21}$ This exercise can be seen as a simple way of estimating bank cost functions. There is a vast technical literature on this subject. See, for instance, Hughes and Mester (2010) for a recent review.
} 
The coefficients for transaction deposits and saving deposits are of primary interest for our cost attribution analysis and are shown in Figure A1. These coefficients are interpretable as the unit noninterest expenses associated with various types of deposit-taking. For instance, the coefficient of 3.4\% for transaction deposits in 1984 means that a bank which was 100\% funded with transaction deposits had an expense ratio 3.4 percentage points higher than the baseline wholesale-funded bank. $^{22}$

Figure A1 shows that estimated unit cost of transaction deposits has fallen steadily over time, from $3.4 \%$ to 1984 to only $0.5 \%$ in 2012 . This downward trend makes sense in light of the numerous technological developments, primarily information technology, that have reduced the costs of deposit-taking. In contrast, Figure A1 shows that the unit cost of savings deposits hovered around $2 \%$ from the late 1980 s to 2008 . However, the costs of savings deposits has fallen sharply in the past 4 years, arguably because banks have benefited from large deposit inflows due to the lowinterest rate environment and expanded FDIC guarantee programs.

Using these cross-sectional regression coefficients as our proxies for the relevant unit costs, we estimate the aggregate noninterest expense associated with deposit-taking activities as

$$
\frac{\text { NONINTEXP }_{t}^{\text {DEP }}}{\text { DEPOSIT }_{t}}=\frac{\text { ASSET }_{t}}{\operatorname{DEPOSIT}_{t}} \times\left(\begin{array}{c}
\hat{\gamma}_{t}^{(\text {TRANS })} \cdot \frac{\text { TRANSDEPOSIT }_{t}}{A S S E T_{t}} \\
\hat{\gamma}_{t}^{(S A V E)} \cdot \frac{\text { SAVEDEPOSIT }_{t}}{A S S E T_{t}} \\
\hat{\gamma}_{t}^{(\text {FOR })} \cdot \frac{\text { FORDEPOSIT }_{t}}{A S S E T_{t}}
\end{array}\right) .
$$

In other words, to come up with an estimate of deposit-related operating costs, we apply our estimated unit costs to the deposit mix of the aggregate banking industry.

Figure A2 shows the time series of estimated profits from deposit taking from 1984 to 2012. We first show the gross deposit spread, $R_{F}-R_{D E P}$, which is the net interest income associated with narrow banking. The interest rates paid on transactional and savings deposit accounts embed a significant convenience premium relative to short-term market rates. As a result, the gross deposit

\footnotetext{
22 The dashed lines are standard error bands and indicate that the parameters are precisely estimated which is natural since there are thousands of banks in each cross-section
} 
spread averages $0.87 \%$ of deposits over our 29 year sample. ${ }^{23}$ We next add noninterest income associated with deposit taking, NONINTINC/DEP, which has averaged $0.49 \%$ of deposits.

Finally, we subtract our estimate of the noninterest expense associated with deposit-taking. While estimated deposit-taking expenses have trended down steadily over time, these expenses are substantial, averaging $1.30 \%$ of deposits. Combining these pieces as in equation (A1), we arrive at our estimates of the profits generated by narrow banking. Between 1984 and 2012, these profits average $0.06 \%$ of deposits.

This $\mathbf{0 . 0 6 \%}$ figure is an upper bound on the profitability of narrow banking. Specifically, as noted above, our attribution of non-interest expenses includes an unallocated fixed overhead cost which is not attributed to deposit-taking or lending at the margin. These overhead costs are significant, and average $0.63 \%$ of deposits from 1984-2012. Thus, one needs to ask how much of these fixed overhead costs should be allocated to deposit-taking. If $50 \%$ of these fixed costs are allocated to deposit-taking, the estimated profitability of narrow banking falls to $-0.25 \%$ on average.

\section{B. Cross-section of Intermediary Types and Cross-section of Assets}

We assemble data on the financial assets and liabilities of various intermediary types from the Federal Reserve's Financial Accounts of the United States (formerly the Flow of Funds Accounts). We examine data on commercial banks, property and casualty (P\&C) insurers, life insurers, money market funds (MMFs), government sponsored enterprises (GSEs), finance companies, real estate investment trusts (REITs), and security broker-dealers.

We exclude a handful of financial sectors included in the Financial Accounts. First, we exclude the Federal Reserve (L.108), taking the view that it should be consolidated with the Federal Government from the standpoint of financial intermediation. Second, we exclude pension funds (L.116), mutual funds (L.121), and closed-end funds and ETFs (L.122) on the theory that these “real money” intermediaries are essentially just veils for the household sector. Third, to avoid double-counting issues we do not treat MBS and ABS issuers as separate sectors. Finally, we exclude Holding Companies (L.129) and Funding Corporations (L.130).

\footnotetext{
${ }^{23}$ As shown in Figure A2, the net interest income generated by deposit-taking is positively related to the level of shortterm interest rates. This is because the rates on transaction and savings deposits adjust very sluggishly to movement in short-term market rates. See Neumark and Sharpe (1992) and English, Van den Heuvel, and Zakrajsek (2012).
} 
For each financial intermediary type, we construct an aggregate balance sheet using data in the Financial Accounts. This requires some straightforward manipulation of the Financial Accounts Data. There are three minor subtleties. First, we do not count GSE-backed MBS-which were consolidated onto their balance sheets following the implementation of FASB 140 in December 2010-as GSE assets. Second, to operationalize equation (17) for banks' market share in each asset class, we compute banks' holdings as a share of all assets held by the domestic Financial Business sector in Table L.107. In other words, we compute banks' share of intermediated assets holdings. Third, for each category of loans (home mortgages, commercial mortgages, multifamily mortgages, consumer loans, and C\& loans) we adjust the amount of outstanding loans to net out securitized loans. Thus, holdings of these assets represent intermediaries' holdings of (whole) loans, whereas holdings of securitizations are accounted for separately as either holdings of GSE-backed MBS or as corporate bonds for private securitizations.

Next we need to choose values for ILLIQUID, MATURITY $_{j}$, and STICKY $Y_{j}$. Our approach is to choose values based on the liquidity risk measurement proposal set forth under Basel III. We use parameter values associated with the BCBS (2010) proposal for the Net Stable Funding Requirement (NSFR) and the final BCBS (2013) Liquidity Coverage Requirement (LCR). First, using BCBS (2010), we use the NSFR's Required Stable Funding factor as a first guide for assigning $I L L I Q U I D_{j}$ and the Available Stable Funding factor as guide for $\operatorname{STICKY}_{j}$. Second, using BCBS (2013), we used the LCR's haircut factor for the computation of High Quality Liquid Assets as a second guide for $I L L I Q U I D_{j}$ and the assumed percentage outflow factor as second guide for STICKY $Y_{j}$. The inputs from the NSFR and LCR are summarized in Table AI.

Our approach is to use these BCBS factors whenever possible. In general, the NFSR and LCR factors paint a similar picture of asset illiquidity and liability maturity and stickiness. However, when the two are in conflict we lean towards the LCR weights, reasoning that the represent the most up-to-date consensus among policy-makers and market participants.

There are some categories such as GSE-debentures and corporate bonds where it does not make sense to assume STICKY = 1 and MATURITY = 1: some of these bond are short-term and are prone to run. Therefore, we assume STICKY $=$ MATURITY $=0.4$ in both cases . 
We also need to assign values for liability types issued by non-banks that are not considered by BCBS (2010, 2013). We are forced to fill in these assumptions. However, we have made every attempt to do so in a way that is consistent with the spirit of Basel III and is motivated by existing empirical evidence wherever possible. The main question here concerns the length and stickiness of the policy-related operating liabilities of life and P\&C insurers. We assume that both life and P\&C policies are fairly illiquid assets with ILLIQUID $=0.4$. In the case of life policy liabilities, we assume STICKY $=$ MATURITY $=0.9$ so the liabilities of life insurers are comparable to retail bank deposits. For P\&C insurers, we assume that STICKY $=$ MATURITY $=0.6$, so the liabilities of P\&C insurers are equivalent to corporate bonds. Our final parameter choices are shown in Table AII.

\section{Policy Analysis}

\section{C.1. Determination of the Fire-Sale Discount}

Before getting into the policy analysis, we need to be a bit more explicit about the origins of the fire-sale discount in our model. Recall the key reduced-form properties we have assumed about this discount, namely that $\partial k\left(\mu_{i}, \varphi_{i}\right) / \partial \mu_{i} \leq 0$, so demand is downward sloping, and that $\partial^{2} k\left(\mu_{i}, \varphi_{i}\right) / \partial \mu_{i} \partial \varphi_{i} \leq 0$, so more illiquid assets have steeper demand curves.

These properties can be micro-founded in an elaborated version of Stein (2012). For each asset $i$, we assume that there is a separate group of $n_{i}$ specialist buyers, who can step in and buy the asset if it is liquidated at time 1. As will become clear momentarily, assets with low values of $n_{i}$ correspond to those with high values of $\varphi_{l}$. In other words, asset illiquidity ultimately derives from the fact that there are relatively few specialist buyers available to absorb a given asset.

Specialist buyers are also owned by households: all their profits accrue to households at time 2. Each individual specialist buyer has war chest of $0<W \leq 1$ available at time 1 , which can be used either to buy up fire-sold assets at a discount, or to invest in new real projects. Each specialist buyer's investment of $K_{i}$ in a new project yields a gross return of $g\left(K_{i}\right)=\log \left(K_{i}\right)$. Recall that liquidated assets sell at a discount $k_{i}$ to their fundamental value of $F_{i}=q R+(1-q) z_{i}$ and thus yield a gross expected return of $1 / k_{i}$ to a specialist buyer who purchases them at time 1 . Since the total volume of liquidations in asset $i$ is $\mu_{i} k_{i} F_{i}$, and since these liquidations must be absorbed by $n_{i}$ specialist buyers, each buyer must absorb $\mu_{i} k_{i} F_{i} / n_{i}$ of the liquidation, investing $K_{i}=W-\mu_{i} k_{i} F_{i} / n_{i}$ in 
new projects. At an interior optimum, the expected return to buying fire-sold assets must be equal to the expected return to investment in the new project, which implies:

$$
1 / k_{i}=g^{\prime}\left(W-\mu_{i} k_{i} F_{i} / n_{i}\right)
$$

Given our functional form assumption that $g\left(K_{i}\right)=\log \left(K_{i}\right)$, this expression boils down to:

$$
k_{i}=\frac{W}{1+\mu_{i} F_{i} / n_{i}} .
$$

Since $n_{i}$ is nothing more than an inverse measure of asset illiquidity $\varphi_{i}$, we now have a micro-founded expression for the fire-sale discount $k_{i}$ with the desired properties that $\partial k\left(\mu_{i}, \varphi_{i}\right) / \partial \mu_{i} \leq 0$ and $\partial^{2} k\left(\mu_{i}, \varphi_{i}\right) / \partial \mu_{i} \partial \varphi_{i} \leq 0$. (The former always holds and the latter holds so long as $n_{i} \geq \mu_{i} F_{i}$ which we henceforth assume). While this micro-founding exercise is extremely simple, it is necessary for the normative analysis that follows. This is because in order to model the social costs of fire sales, we need to relate the costs to the foregone real investment by the specialist buyers that is an inevitable consequence of these fire sales. With this bit of machinery in place, we can now examine the policy implications of the model.

\section{C.2. Policy Analysis}

Since households own shadow banks, traditional banks, and specialist buyers, the household utility associated with asset $i$ equals the value of all shadow banking and traditional banking claims backed by asset $i$ plus the expected profits earned by associated specialist buyers

$$
U_{i}=\mu_{i} V_{i}^{S}\left(\mu_{i}\right)+\left(1-\mu_{i}\right) V_{i}^{B}+\beta n_{i}\left(E\left[g\left(K_{i}\right)-K_{i}\right]+(1-p)\left(\mu_{i} k_{i} F_{i} / n_{i}\right)\left(1 / k_{i}-1\right)\right) .
$$

As shown in (C3), the expected profits earned by each specialist buyer are the sum of their expected net return on new real investment, $E\left[g\left(K_{i}\right)-K_{i}\right]$, plus their expected net return on asset purchases in the bad state, $(1-p)\left(\mu_{i} k_{i} F_{i} / n_{i}\right)\left(1 / k_{i}-1\right)$.

However, since the fire-sale losses incurred by shadow banks represent a gain for specialist buyers, the terms of trade between these intermediaries cancel out from the standpoint of household welfare. As a result, the relative size of the traditional banking and shadow banking sectors only impacts household welfare in two ways: the initial amount of monetary services enjoyed by households and the magnitude of the fire-sale problem as captured by the amount of specialist buyer output following the bad state at time 1. One can think of the latter as a stand-in for the severity of 
the collapse in real output if bad news arrives at time 1, triggering a financial crisis. Specifically, ignoring irrelevant constants, initial household utility is given by

$$
\begin{aligned}
U_{i} & =\gamma M_{i}+\beta(1-p) n_{i}\left[g\left(K_{i}\right)-K_{i}\right] \\
& =\gamma\left[\mu_{i} k_{i} F_{i}+\left(1-\mu_{i}\right) z_{i}\right]+\beta(1-p) n_{i}\left[g\left(W-\mu_{i} k_{i} F_{i} / n_{i}\right)-\left(W-\mu_{i} k_{i} F_{i} / n_{i}\right)\right] .
\end{aligned}
$$

The second line of equation (C4) follows from the fact that the total amount of money created by shadow banks and traditional banks using asset $i$ as backing is $M_{i}=\mu_{i} k_{i} F_{i}+\left(1-\mu_{i}\right) z_{i}$ plus the fact that each specialists' investment in new real projects in the bad state is $K_{i}=W-\mu_{i} k_{i} F_{i} / n_{i}$.

Since intermediaries pick $\mu_{i}$ taking $k_{i}$ as given, a private market equilibrium corresponds to

$$
\left.\max _{\mu_{i} \in[0,1]}\left\{\gamma\left[\mu_{i} k_{i}^{*} F_{i}+\left(1-\mu_{i}\right) z_{i}\right]+\beta(1-p) n_{i}\left[g\left(W-\mu_{i} k_{i}^{*} F_{i} / n_{i}\right)\right)-\left(W-\mu_{i} k_{i}^{*} F_{i} / n_{i}\right)\right]\right\},
$$

where we use one star to denote the private market solution. Recalling that $1=k_{i} g^{\prime}\left(W-\mu_{i} k_{i} F_{i} / n_{i}\right)$, the first order condition for (C5) implies that an interior private market equilibrium satisfies

$$
\overbrace{\left[\gamma k_{i}^{*}-(1-p) \beta\left(1-k_{i}^{*}\right)\right] F_{i}}^{\begin{array}{c}
\text { Net private benefit } \\
\text { shadow banking }
\end{array}}=\overbrace{\left[\gamma Z_{i}\right]}^{\begin{array}{c}
\text { Net private benefit } \\
\text { traditional banking }
\end{array}}
$$

which is equivalent to equation (6) in the main text.

Relative to the private market equilibrium, the social planner's solution also takes into account the fact that $k_{i}^{\prime}\left(\mu_{i}\right)<0$. Specifically, a social optimum corresponds to

$$
\max _{\mu_{i} \in[0,1]}\left\{\begin{array}{c}
\gamma\left[\mu_{i} k_{i}\left(\mu_{i}\right) F_{i}+\left(1-\mu_{i}\right) z_{i}\right] \\
\left.+\beta(1-p) n_{i}\left[g\left(W-\mu_{i} k_{i}\left(\mu_{i}\right) F_{i} / n_{i}\right)\right)-\left(W-\mu_{i} k_{i}\left(\mu_{i}\right) F_{i} / n_{i}\right)\right]
\end{array}\right\} .
$$

Recalling that $1=k_{i}\left(\mu_{i}\right) g^{\prime}\left(W-\mu_{i} k_{i}\left(\mu_{i}\right) F_{i} / n_{i}\right)$, an interior social optimum must satisfy

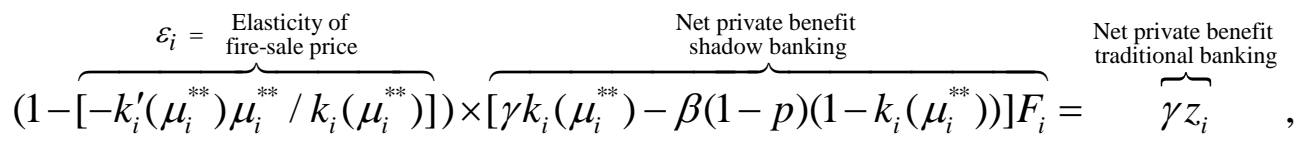

where we use two stars to denote the social planner's solution. Relative to (C6), the net private benefit of shadow banking is reduced by a factor that depends on the elasticity of the first-sale price with respect to $\mu_{i}, \varepsilon_{i}=k_{i}^{\prime}\left(\mu_{i}\right) \mu_{i} / k_{i}$. As a result, when $\gamma z_{i}>0$, a social planner would like to lower the amount of shadow banking intermediation relative to the private market.

A planner can implement the social optimum in our model by imposing a minimum haircut requirement on the amount of repo that shadow banks can issue to MMFs. Although the private market imposes a haircut, the planner needs to require even larger haircuts so shadow banks can 
only create $\left(k_{i}^{* *}-h_{i}^{* *}\right) F_{i}<k_{i}^{* *} F_{i}$ of safe repo using asset $i$ as collateral. Specifically, (C8) implies that the social optimum can be implemented by imposing an additional haircut of

$$
h_{i}^{* *}=\overbrace{\varepsilon_{i}}^{\substack{\text { Elasticity of } \\
\text { fire-sale price }}} \times \overbrace{\left[\gamma k_{i}\left(\mu_{i}^{* *}\right)-\beta(1-p)\left(1-k_{i}\left(\mu_{i}^{* *}\right)\right)\right]}^{\begin{array}{c}
\text { Net private benefit } \\
\text { shadow banking }
\end{array}}=\frac{\varepsilon_{i}}{1-\varepsilon_{i}} \times \frac{\gamma z_{i}}{F_{i}}>0 .
$$

Finally, given our assumption that $g\left(K_{i}\right)=\log \left(K_{i}\right)$, we have

$$
\varepsilon_{i}=\frac{-k_{i}^{\prime}\left(\mu_{i}\right) \mu_{i}}{k_{i}\left(\mu_{i}\right)}=\frac{\mu_{i} F_{i}}{\mu_{i} F_{i}+n_{i}},
$$

so, all else equal, the elasticity of the fire-sale price with respect to $\mu_{i}$ is greatest for assets with few specialist buyers $n_{i}$ (i.e., for illiquid assets with large values of $\varphi_{i}$ ). 
Figure A1: Noninterest Expense Attribution Regressions. Estimates of unit costs for transaction and saving deposits from 1984-2012.

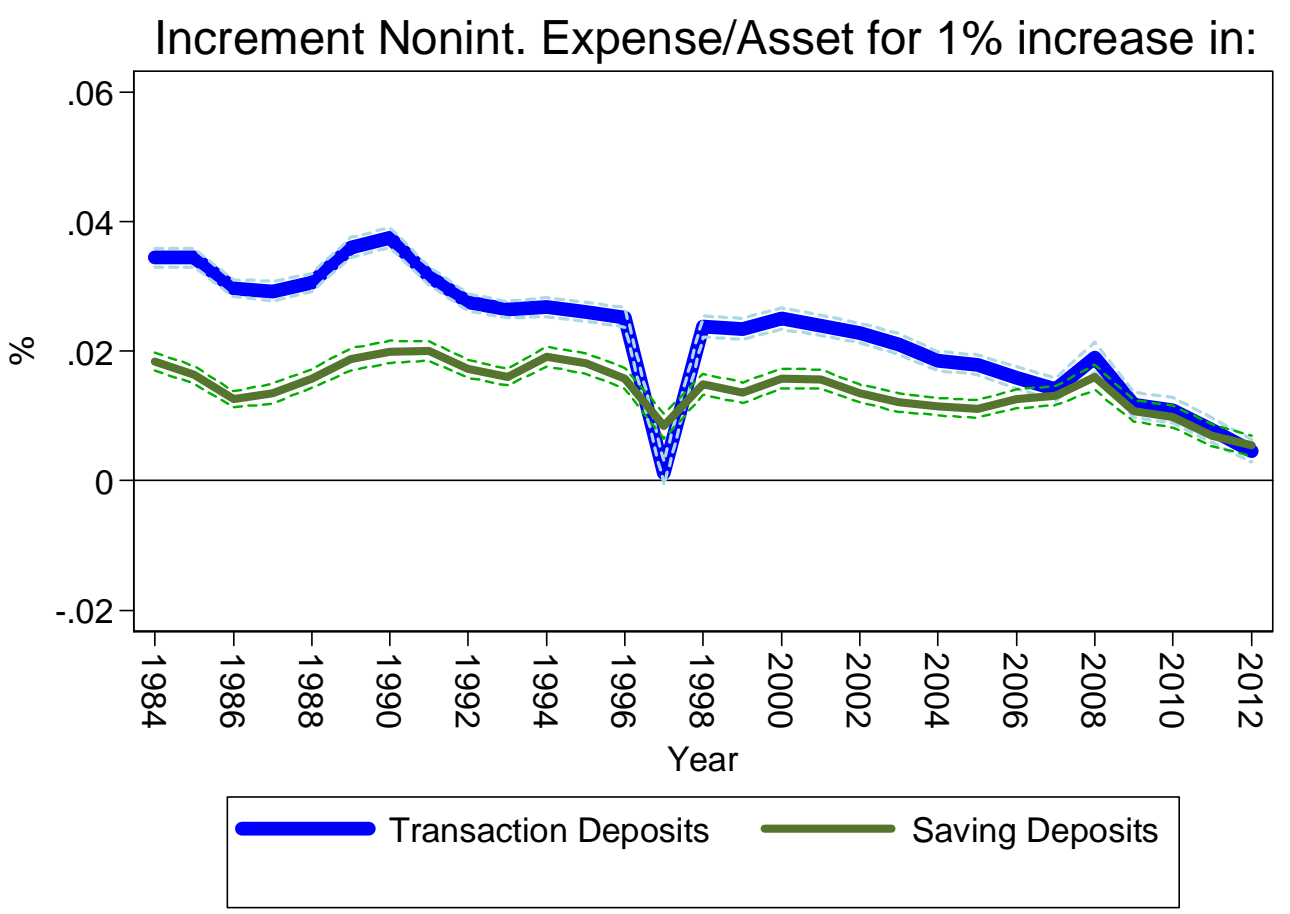

Figure A2: Estimating the Profitability of Narrow Banking. This figure shows our decomposition of the aggregate profitability of commercial bank deposit taking from 1984-2012.

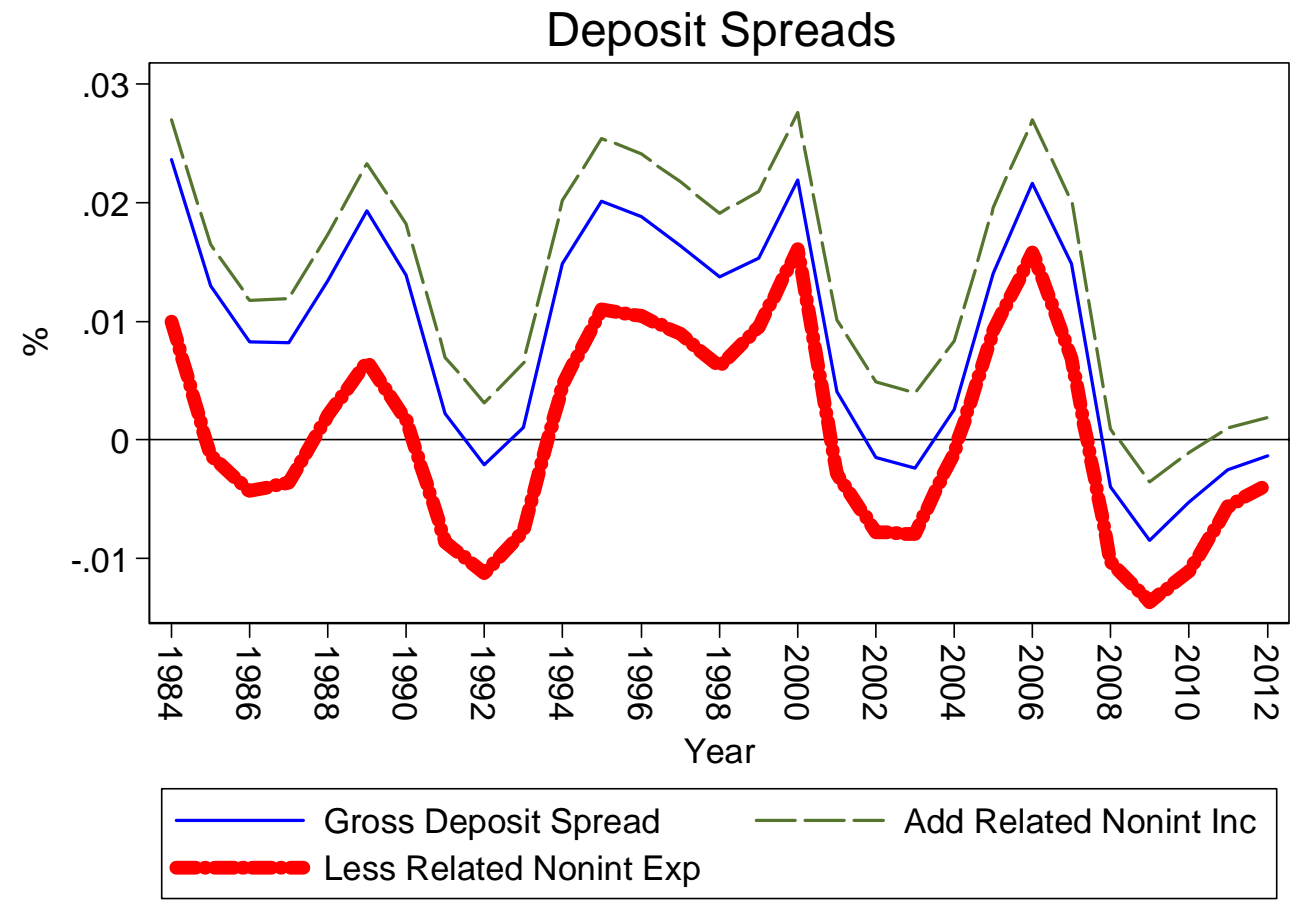


Table AI: Parameters Drawn from the Basel III NFSR and LCR Liquidity Requirements: The Net Stable Funding Ratio (NSFR) factors are based on BCBS (2010). The Liquidity Coverage Ratio (LCR) factors are based on BCBS (2013). Long-term means having a contractual maturity greater than 1 year.

\begin{tabular}{|c|c|c|c|c|c|c|}
\hline \multirow[b]{2}{*}{ Instrument } & \multicolumn{3}{|c|}{ Net Stable Funding Ratio factors } & \multicolumn{3}{|c|}{ "Liquidity Coverage Ratio factors } \\
\hline & ILLIQUID & STICKY & LENGTH & ILLIQUID & STICKY & LENGTH \\
\hline Common Equity & & $100 \%$ & $100 \%$ & & $100 \%$ & $100 \%$ \\
\hline Preferred Stock & & $100 \%$ & $100 \%$ & & $100 \%$ & $100 \%$ \\
\hline Long-term debt and all long-term time deposits & & $100 \%$ & $100 \%$ & & $100 \%$ & $100 \%$ \\
\hline Insured retail demand deposits and short-term $(<1 \mathrm{yr})$ retail time deposits & & $90 \%$ & $0 \%$ & & $97 \%$ & $0 \%$ \\
\hline Uninsured retail demand deposits and short-term $(<1 \mathrm{yr})$ retail time deposits & & $80 \%$ & $0 \%$ & & $90 \%$ & $0 \%$ \\
\hline Short-term wholesale funding, including wholesale deposits. & & $50 \%$ & $0 \%$ & & & \\
\hline Other Liabilities & & $0 \%$ & $0 \%$ & & & \\
\hline Short-term unsecured whole-sale funding from small business cutomers & & & & & $90 \%$ & $0 \%$ \\
\hline Short-term unsecured whole-sale funding from clearing, custody, and cash-management & & & & & $75 \%$ & $0 \%$ \\
\hline Short-term unsecured whole-sale funding from large business customers (insured) & & & & & $80 \%$ & $0 \%$ \\
\hline Short-term unsecured whole-sale funding from large business customers (uninsured) & & & & & $60 \%$ & $0 \%$ \\
\hline Short-term secured whole-sale funding (depends on collateral) & & & & & & \\
\hline Money market instruments (short-term low default risk debt) & $0 \%$ & & & $0 \%$ & & \\
\hline Long-term Treasuries & $5 \%$ & & & $0 \%$ & & \\
\hline GSE-backed MBS and debt & $20 \%$ & & & $15 \%$ & & \\
\hline Corporate bonds rated AA- or higher & $20 \%$ & & & $15 \%$ & & \\
\hline RMBS & & & & $25 \%$ & & \\
\hline Equity: must be large-cap index and listed on a public exchange & $50 \%$ & & & $50 \%$ & & \\
\hline Corporate bonds rated A- or higher for NFSR (BBB- or higher for LCR) & $50 \%$ & & & $50 \%$ & & \\
\hline Commercial and industrial loans & $100 \%$ & & & $100 \%$ & & \\
\hline Residential mortgage loans & $65 \%$ & & & $100 \%$ & & \\
\hline Other loans & $65 \%$ & & & $100 \%$ & & \\
\hline Consumer loans & $85 \%$ & & & $100 \%$ & & \\
\hline Other assets & $100 \%$ & & & $100 \%$ & & \\
\hline
\end{tabular}


Table AII: Instrument Parameters Values Used in Our Exercise: This table lists the instrument names found in the Financial Accounts and the values of ILLIQUID, LENGTH, and STICKY assigned to those instruments.

\begin{tabular}{|c|c|c|c|}
\hline Instrument Name in the Financial Accounts & ILLIQUID (assets) & LENGTH (liabilities) & "STICKY (liabilities) \\
\hline Agency- and GSE-backed securities & $15 \%$ & $60 \%$ & $60 \%$ \\
\hline Bank loans not elsewhere classified & $100 \%$ & $100 \%$ & $100 \%$ \\
\hline Bankers' Acceptances & $0 \%$ & $0 \%$ & $0 \%$ \\
\hline Checkable deposits & $0 \%$ & $0 \%$ & $90 \%$ \\
\hline Checkable deposits and currency & $0 \%$ & $0 \%$ & $90 \%$ \\
\hline Commercial mortgages & $100 \%$ & $100 \%$ & $100 \%$ \\
\hline Consumer credit & $75 \%$ & $100 \%$ & $100 \%$ \\
\hline Consumer leases & $75 \%$ & $100 \%$ & $100 \%$ \\
\hline Corporate and foreign bonds & $50 \%$ & $60 \%$ & $60 \%$ \\
\hline Corporate equities & $50 \%$ & $100 \%$ & $100 \%$ \\
\hline Currency & $0 \%$ & $0 \%$ & $0 \%$ \\
\hline Customers' liability on acceptances outstanding & $0 \%$ & $0 \%$ & $0 \%$ \\
\hline Depository institution reserves & $0 \%$ & $0 \%$ & $80 \%$ \\
\hline Deposits at Federal Home Loan Banks & $0 \%$ & $0 \%$ & $80 \%$ \\
\hline Direct investment & $100 \%$ & $100 \%$ & $60 \%$ \\
\hline Equity in government-sponsored enterprises (GSEs) & $100 \%$ & $100 \%$ & $100 \%$ \\
\hline Farm mortgages & $100 \%$ & $100 \%$ & $100 \%$ \\
\hline Federal funds and security repurchase agreements & $0 \%$ & $0 \%$ & $0 \%$ \\
\hline Government-sponsored enterprise (GSE) loans & $15 \%$ & $60 \%$ & $60 \%$ \\
\hline Holding companies net transactions with subsidiaries & $100 \%$ & $100 \%$ & $100 \%$ \\
\hline Home mortgages & $75 \%$ & $100 \%$ & $100 \%$ \\
\hline Large time deposits & $0 \%$ & $10 \%$ & $70 \%$ \\
\hline Life insurance reserves & $80 \%$ & $90 \%$ & $90 \%$ \\
\hline $\mathrm{P} \& \mathrm{C}$ insurance reserves & $80 \%$ & $60 \%$ & $60 \%$ \\
\hline Money market mutual fund shares & $0 \%$ & $0 \%$ & $0 \%$ \\
\hline Multifamily residential mortgages & $100 \%$ & $100 \%$ & $100 \%$ \\
\hline Municipal securities and loans & $50 \%$ & $100 \%$ & $100 \%$ \\
\hline Mutual fund shares & $50 \%$ & $100 \%$ & $100 \%$ \\
\hline Net interbank transactions & $20 \%$ & $0 \%$ & $0 \%$ \\
\hline Nonfinancial business loans & $100 \%$ & $100 \%$ & $100 \%$ \\
\hline Open market paper & $0 \%$ & $0 \%$ & $0 \%$ \\
\hline Other loans and advances & $100 \%$ & $100 \%$ & $100 \%$ \\
\hline Pension entitlements & $80 \%$ & $90 \%$ & $90 \%$ \\
\hline Private foreign deposits & $0 \%$ & $10 \%$ & $20 \%$ \\
\hline Securities borrowed (net) & $0 \%$ & $10 \%$ & $20 \%$ \\
\hline Security credit & $0 \%$ & $10 \%$ & $20 \%$ \\
\hline Small time and savings deposits & $0 \%$ & $0 \%$ & $80 \%$ \\
\hline Syndicated loans to nonfinancial corporate business & $100 \%$ & $100 \%$ & $100 \%$ \\
\hline Taxes payables & $0 \%$ & $0 \%$ & $0 \%$ \\
\hline Total miscellaneous assets & $100 \%$ & $100 \%$ & $100 \%$ \\
\hline Total miscellaneous liabilities & $100 \%$ & $100 \%$ & $100 \%$ \\
\hline Total time and savings deposits & $0 \%$ & $0 \%$ & $80 \%$ \\
\hline Trade payables & $60 \%$ & $0 \%$ & $0 \%$ \\
\hline Trade receivables & $60 \%$ & $0 \%$ & $0 \%$ \\
\hline Treasury securities & $0 \%$ & $0 \%$ & $0 \%$ \\
\hline U.S. government loans & $0 \%$ & $0 \%$ & $0 \%$ \\
\hline Unidentified miscellaneous assets & $100 \%$ & $100 \%$ & $100 \%$ \\
\hline Unidentified miscellaneous liabilities & $100 \%$ & $100 \%$ & $100 \%$ \\
\hline
\end{tabular}

